\title{
Article
}

\section{Dates, Diet, and Dismemberment: Evidence from the Coldrum Megalithic Monument, Kent}

\author{
Wysocki, Michael Peter, Griffiths, Seren, Hedges, Robert, Bayliss, \\ Alex, Higham, Tom, Fernandez-Jalvo, Yolanda and Whittle, Alasdair \\ Available at http://clok.uclan.ac.uk/10742/ \\ Wysocki, Michael Peter, Griffiths, Seren, Hedges, Robert, Bayliss, Alex, \\ Higham, Tom, Fernandez-Jalvo, Yolanda and Whittle, Alasdair (2013) Dates, \\ Diet, and Dismemberment: Evidence from the Coldrum Megalithic Monument, \\ Kent. Proceedings of the Prehistoric Society, 79 . pp. 61-90. ISSN 0079-497X
}

It is advisable to refer to the publisher's version if you intend to cite from the work. http://dx.doi.org/10.1017/ppr.2013.10

For more information about UCLan's research in this area go to http://www.uclan.ac.uk/researchgroups/ and search for <name of research Group>.

For information about Research generally at UCLan please go to http://www.uclan.ac.uk/research/

All outputs in CLoK are protected by Intellectual Property Rights law, including Copyright law. Copyright, IPR and Moral Rights for the works on this site are retained by the individual authors and/or other copyright owners. Terms and conditions for use of this material are defined in the policies page.

\section{CLoK}

Central Lancashire online Knowledge www.clok.uclan.ac.uk

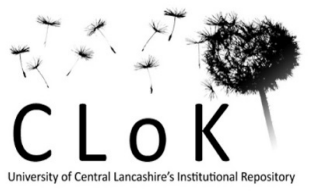




\section{Proceedings of the Prehistoric Society}

http://journals.cambridge.org/PPR

Additional services for Proceedings of the Prehistoric Society:

Email alerts: Click here

Subscriptions: Click here

Commercial reprints: Click here

Terms of use : $\underline{\text { Click here }}$

\section{Dates, Diet, and Dismemberment: Evidence from the Coldrum Megalithic Monument, Kent}

Michael Wysocki, Seren Griffiths, Robert Hedges, Alex Bayliss, Tom Higham, Yolanda Fernandez-Jalvo and Alasdair Whittle

Proceedings of the Prehistoric Society / FirstView Article / July 2013, pp 1 - 30

DOI: 10.1017/ppr.2013.10, Published online: 17 July 2013

Link to this article: http://journals.cambridge.org/abstract_S0079497X13000108

How to cite this article:

Michael Wysocki, Seren Griffiths, Robert Hedges, Alex Bayliss, Tom Higham, Yolanda Fernandez-Jalvo and Alasdair Whittle Dates, Diet, and Dismemberment: Evidence from the Coldrum Megalithic Monument, Kent. Proceedings of the Prehistoric Society, Available on CJO 2013 doi:10.1017/ppr.2013.10

Request Permissions : $\underline{\text { Click here }}$ 


\title{
Dates, Diet, and Dismemberment: Evidence from the Coldrum Megalithic Monument, Kent
}

\author{
By MICHAEL WYSOCKI ${ }^{1}$, SEREN GRIFFITHS ${ }^{2}$, ROBERT HEDGES ${ }^{3}$, ALEX BAYLISS ${ }^{4}$, TOM HIGHAM ${ }^{3}$, \\ YOLANDA FERNANDEZ-JALVO ${ }^{5}$ and ALASDAIR WHITTLE ${ }^{2}$
}

We present radiocarbon dates, stable isotope data, and osteological analysis of the remains of a minimum of 17 individuals deposited in the western part of the burial chamber at Coldrum, Kent. This is one of the Medway group of megalithic monuments - sites with shared architectural motifs and no very close parallels elsewhere in Britain - whose location has been seen as important in terms of the origins of Neolithic material culture and practices in Britain. The osteological analysis identified the largest assemblage of cut-marked human bone yet reported from a British early Neolithic chambered tomb; these modifications were probably undertaken as part of burial practices. The stable isotope dataset shows very enriched $\delta^{15} \mathrm{~N}$ values, the causes of which are not entirely clear, but could include consumption of freshwater fish resources. Bayesian statistical modelling of the radiocarbon dates demonstrates that Coldrum is an early example of a British Neolithic burial monument, though the tomb was perhaps not part of the earliest Neolithic evidence in the Greater Thames Estuary. The site was probably initiated after the first appearance of other early Neolithic regional phenomena including an inhumation burial, early Neolithic pottery and a characteristic early Neolithic post-and-slot structure, and perhaps of Neolithic flint extraction in the Sussex mines. Coldrum is the only site in the Medway monument group to have samples which have been radiocarbon dated, and is important both for regional studies of the early Neolithic and wider narratives of the processes, timing, and tempo of Neolithisation across Britain.

Keywords: early Neolithic, megalithic monument, human remains, radiocarbon dates, Bayesian statistics, cut-marks

Coldrum is one of the Medway group of megalithic monuments (Alexander 1959; 1962; Ashbee 1993; 2000; 2005; Barber 2004; Bennett 1913; Bewley et al. 2004; Clarke 1982; Daniel 1950; Evans 1950; Holgate 1981; Jessup 1970): nine constructions apparently grouped around the river Medway, Kent, as it cuts

\footnotetext{
${ }^{1}$ School of Forensic and Investigative Sciences, University of Central Lancashire, Preston, Lancashire, PR1 2HE, UK

${ }^{2}$ Department of Archaeology and Conservation, Cardiff University, John Percival Building, Colum Drive, Cardiff, CF10 3EU, UK

${ }^{3}$ Research Laboratory for Archaeology and the History of Art, University of Oxford, Dyson Perrins Building, South Parks Road, Oxford, OX1 3QY, UK

${ }^{4}$ English Heritage, 1 Waterhouse Square, 138-42 Holborn, London, EC1N 2ST, UK

${ }^{5}$ Museo Nacional de Ciencias Naturales, José Gutiérrez

Abascal 2, 28006 Madrid, Spain
}

through the North Downs (Fig. 1). The monuments lie in two clusters along the southern scarp of the North Downs, east and west of the Medway, with both good access to the river and one of the lowest fords over the river, a natural crossing at Aylesford (Jessup 1970, 95). Together with Addington long barrow (Jessup 1970) and Chestnuts (Alexander 1962), Coldrum forms the eastern group, while the more poorly preserved western group, some $8-10 \mathrm{~km}$ distant, includes Kit's Coty (Fig. 1). Other early Neolithic sites in close proximity include the postand-slot structures at White Horse Stone and Pilgrim's Way (Glass 2000; Hayden \& Stafford 2006; Garwood 2011; Booth et al. 2011; cf. Ashbee 2005).

The Medway monuments appear geographically isolated from larger groups of early Neolithic monuments such as those in Yorkshire and Lincolnshire, and the Cotswold-Severn region. The group does 


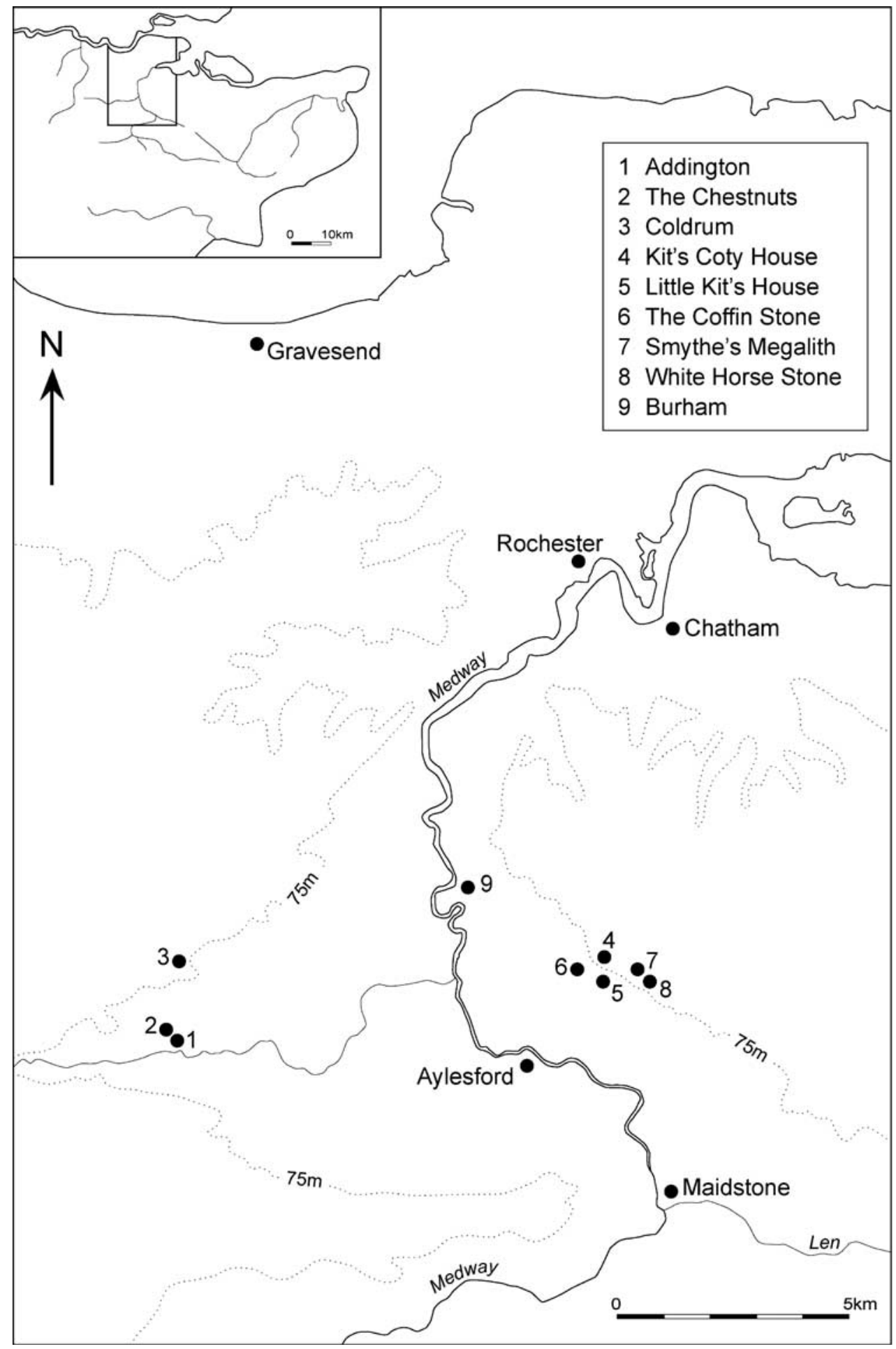

Fig. 1.

The location of Coldrum and other Medway Neolithic monuments 
share some defining architectural motifs, which have no very close parallels elsewhere in Britain and which suggest regional cohesion: massive rectangular chambers in the eastern end of mounds, chambers compartmentalised with medial stones, and rectangular mounds with peristaliths (Holgate 1981; Kinnes 1992; 2004; cf. Ashbee 1993; 2005, 112; Jessup 1970, 111). However, as with other regional groupings, such as the Costwold-Severn tombs, there are also idiosyncracies and diversity: the rectilinear shape at Coldrum, the façade at Chestnuts, and the long thin mounds at Addington and Kit's Coty House. As the only dated site - and the only site likely to be dated (see below) - Coldrum plays an important role in understanding the development of regional Neolithic burial practices, though without further scientific dating the relationships of these sites within such traditions will remain a matter for speculation.

Origins or influences have been suggested from sources including Scandinavia (Daniel 1950), Germany (Evans 1950), and the Low Countries (Piggott 1935), though it is to be noted that those discussions belonged to an era with different chronologies to those available today. Jessup (1970) and Holgate (1981, 230-1) emphasised the strategic position of Kent as 'a leading reception centre for continental imports, immigrants and visitors throughout the Neolithic'. No obvious single precedents can be identified. The geographically closest continental monuments, for example at Wéris in eastern Belgium, while bearing some general similarity in terms of box-like chambers, belong to late Neolithic traditions of the late 4th and into the 3rd millennia cal BC (Toussaint 2003; Toussaint et al. 2009). Western Belgium appears largely devoid of megalithic monuments (Toussaint 2003). Further potential continental connections include the proximity of eastern Kent pit sites to middle Neolithic sites on the adjacent continent (such as in the Pasde-Calais; cf. Sheridan 2010).

Antiquarian and archaeological research at Coldrum was detailed by the late Paul Ashbee (1998, 42-3). There was no capstone in the 1840 s when the first known drawings of the monument were made. A reconstruction by Evans $(1950,73)$ emphasised the 'square' morphology, devoid of fore-court 'horns' common in many Cotswold-Severn or Yorkshire and Lincolnshire long barrows. The site now consists of a low rectangular mound, $c$. 15 by $15 \mathrm{~m}$, orientated east-west, with a partly ruined revetment of sarsens. A rectangular (c. 4 by $1.5 \mathrm{~m}$ ) chamber of four massive sarsens is located at the east end. The monument sits on the edge of a terrace, with collapsed sarsens located at its foot (Evans 1950, 74; Jessup 1970, 108). The chamber was divided into east and west compartments by orthostats, possibly forming a porthole entrance; these had collapsed or been removed by the 1890s (Bennett 1913).

HISTORY OF ANTIQUARIAN RESEARCH, EXCAVATION, AND THE ARCHIVE

The earliest existing plans are found in the mid-19th century Beale Post manuscript, which also records that two 'sculls' were recovered from the site in 1804 and 1825 (Evans 1949, 132, 137; Ashbee 1998, 2). Human remains were removed at intervals until 1893 (Bennett 1913; Evans 1950).

In 1910, the geologist and antiquary F.J. Bennett surveyed the monument, and excavated the apparently undisturbed western part of the chamber, simply digging down to recover human skeletal remains from two levels or 'platforms' (Bennett 1913; Ashbee 1998, 20-2; Figs 2-3). Plans and sections from this excavation were drawn by E.W. Filkins. A single potsherd, recovered from the surface, and identified as plain Neolithic A ware by Piggottt (1931, 93), was later reliably reclassified as Anglo-Saxon, and is now missing (Giles Guthrie, pers. comm.).

Bennett $(1913,81)$ recovered two skulls, teeth and bone, rude pottery, and a flint saw on 'platform 1', a level identified in the north-west corner of the chamber and close to the south wall, the few stone slabs suggesting to him some sort of paved floor.

Substantial undisturbed human remains were discovered in two groups $c .75 \mathrm{~cm}$ below this, on stone slabs which Bennett interpreted as a second 'platform' (Fig. 3). Six skulls and post-cranial parts lay against the terminal orthostat at the west of the chamber. A second discrete bone group consisting of two skulls and further post-cranial remains occupied the central area of the west compartment. Such distributions are similar to examples at Lanhill, West Kennet, Pipton, and Penywyrlod (Keiller \& Piggott 1938; Piggott 1962, Bayliss et al. 2007b; Savory 1956; 1984; Wysocki \& Whittle 2000). Importantly for the site chronology, we can relate four skulls to the levels identified by Bennett (1913); this is not the case with the post-cranial material.

Bennett (1913) interpreted the platforms as in situ superimposed Neolithic stone pavements. While this 


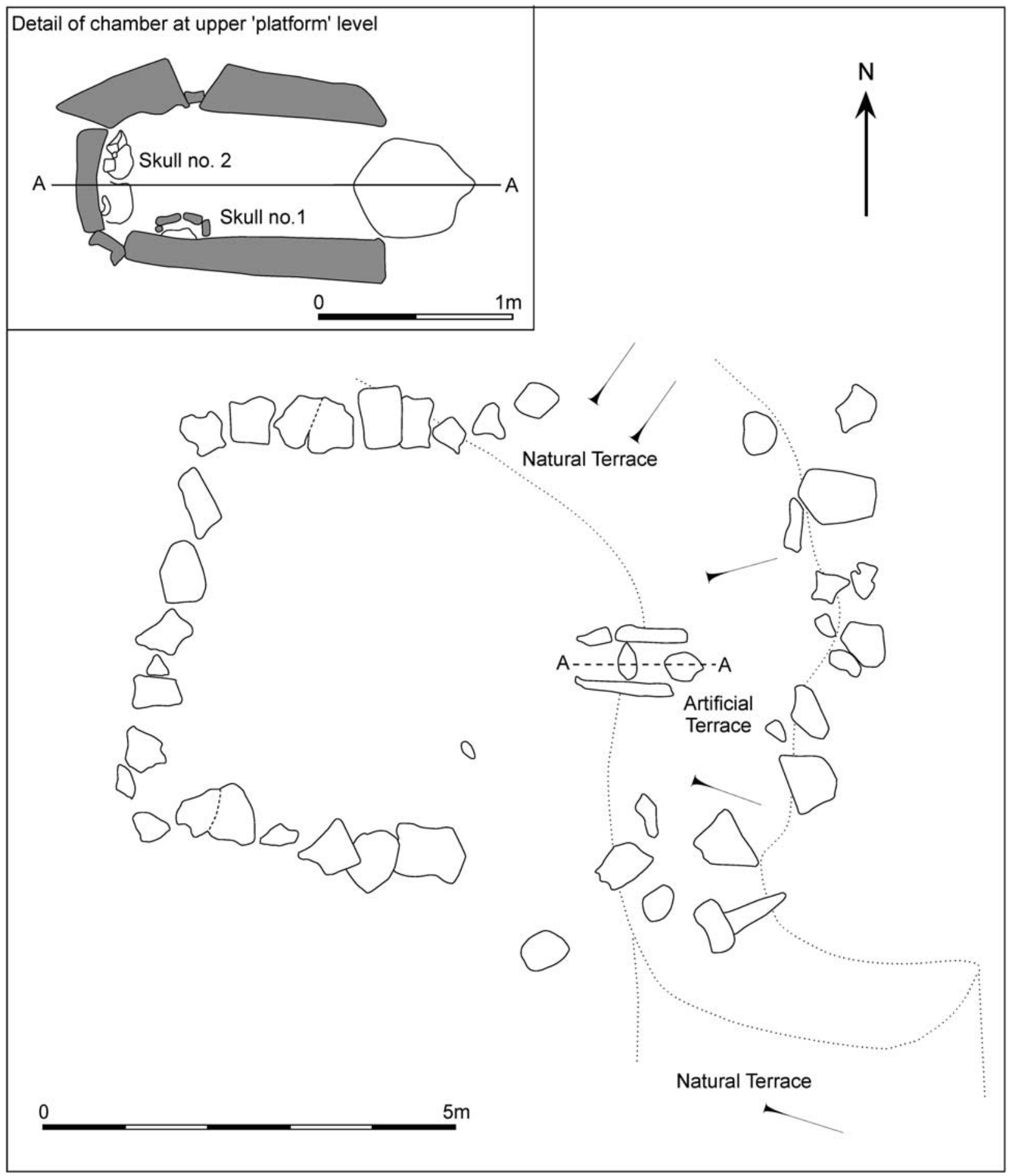

Fig. 2 .

The plan of the Coldrum monument, with a detail of the chamber at the level of 'platform 1' (adapted from Bennett 1913) 


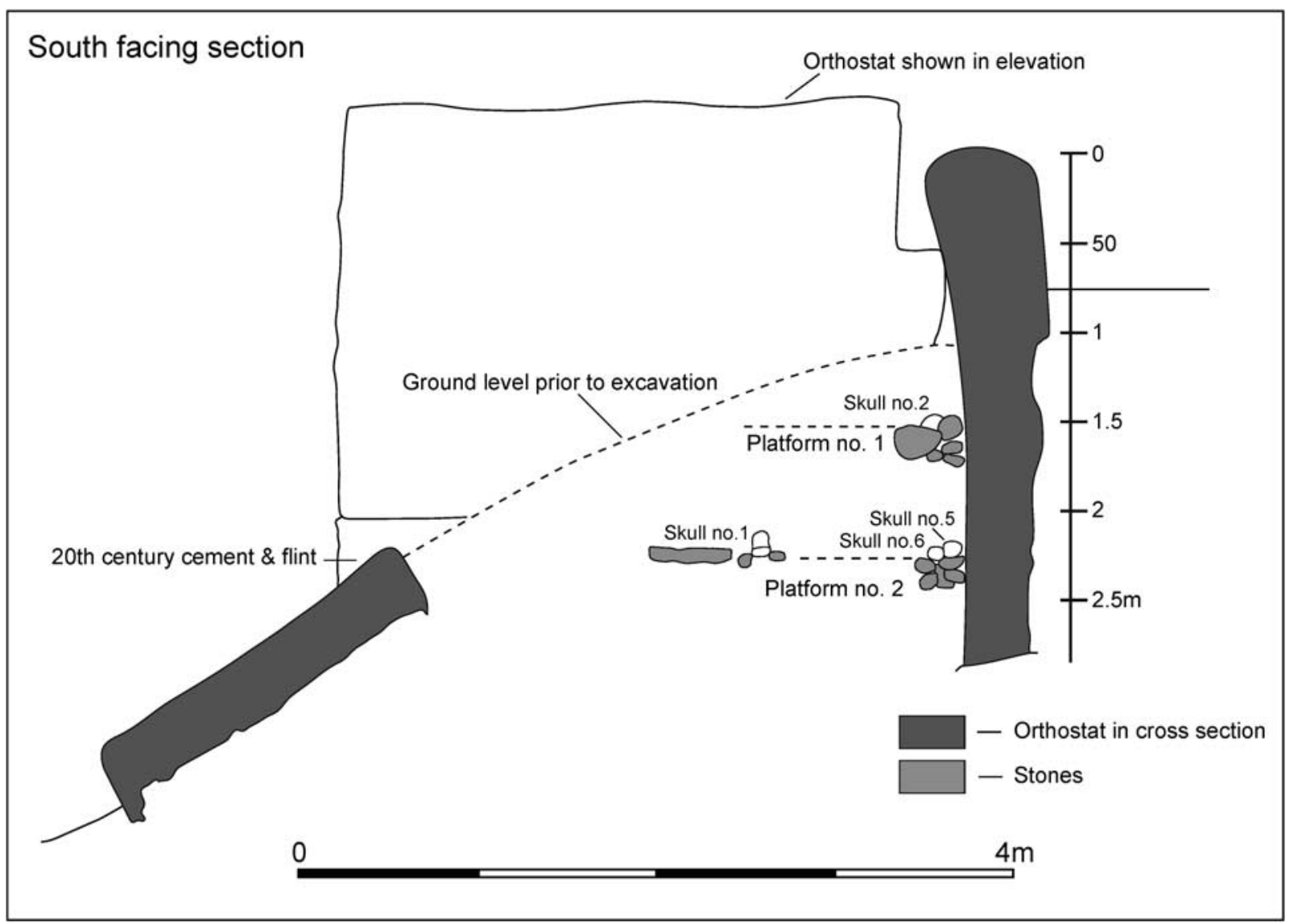

Fig. 3.

The platforms identified by Bennett (adapted from Bennett 1913); it is now only possible to associate four skulls with these levels

is not inconceivable, such an arrangement is almost unprecedented in southern British Neolithic monuments, although something similar has been noted at Le Déhus, Guernsey, and Broadsands in Devon (Schulting et al. 2010b; Sheridan et al. 2008). There is a possibility that finds on the first 'platform' were redeposited upcast from previous disturbances in the eastern half of the chamber. Alternatively, the upper level finds could represent chamber infilling as at West Kennet, where human remains were incorporated with chalk rubble, pottery, and other artefacts (Piggott 1962; Bayliss et al. 2007b).

Filkins, earlier the draughtsman who produced the drawings for Bennett's report, continued excavating in the chamber in 1922, 1923, and 1926 after Bennett's death (Filkins 1928; Ashbee 1998), and recovered further scattered, residual fragmentary human remains.
Most of the human material recovered by Bennett and Filkins was held together at the Royal College of Surgeons (RCS) until the Second World War. Subsequently the post-cranial remains were transferred to the Natural History Museum, London, and the skulls to the Duckworth Laboratory Collection, Cambridge. A small assemblage of human and animal bone recovered from Coldrum by Bennett was presented to Trottiscliffe Parish Church and is now stored at the Maidstone Museum and Bentlif Art Gallery, Maidstone.

\section{AIMS OF THIS STUDY}

Coldrum is the only Medway monument to have yielded substantial human remains (Mays 2004). The Chestnuts produced two human teeth and cremated bone (Alexander 1962). The other Medway monuments 
were built on acid soils, or were extensively robbed (Jessup 1970; Holgate 1981). This study presents osteological analysis, Bayesian modelling of radiocarbon dates, and carbon and nitrogen stable isotope analysis to inform on the demography, burial practices, diet and subsistence, and chronology of the Coldrum population.

\section{OSTEOLOGICAL ANALYSIS}

The skeletal remains were analysed using methods, techniques, and data presented in Buikstra \& Ubelaker (1994); Steele \& Bramblett (1988); Scheuer \& Black (2000), Bass (1992), White (2000), and Hillson (1996).

\section{Human remains from the Bennett excavations}

Keith (1913) suggested that the Bennett assemblage represented 22 individuals, but this is probably an over-estimate (cf. Wysocki \& Whittle 2000). We estimate - on the basis of anatomical duplication in adult left femora and developmental age-related differences in immature left and right femora - that the minimum number of individuals (MNI) is 17 (White 2000, 291-2). We have identified nine adults (probably five males and four females), two older subadults (probably 16-20 years old), four older children, and two younger children (one around 5 years of age, the other of 24-30 months). Four adults were aged c. 20-40+ years, and one older female may have been over 50 years.

\section{Human remains from the Filkins excavations}

The human remains recovered by Filkins (1928) cannot be robustly associated with burial contexts; some were recovered from the western part of the chamber, others from the eastern part. The Filkins cranial assemblage includes fragments of vault and occipital bone, ten petrous temporal portions (six from the right side, four from the left), and parts of six maxillae with dentition. The majority of the remains are hand and foot bones. Duplications of right metatarsal $\mathrm{I}$ indicate a minimum of 11 adults. Two immature metatarsals (IV and V) are probably from a sub-adult of 12-16 years and two immature foot phalanges may be from a child. Sex assessments of the calcanei and tali (Steele \& Bramblett 1988) indicate the presence of six possible males and two females. It is uncertain if any of these fragments represent additional individuals to the 17 already identified, as many of those cranial remains are incomplete in the regions represented in the Bennett assemblage.

\section{Human taphonomy}

Keith (1913) argued that many of the Coldrum bones were deliberately broken around the time of deposition (cf. Keith 1916; Daniel 1950). As currently understood, the assemblage does not support such a view. Fracture morphologies of the limb shafts (almost invariably transverse and right-angled) are consistent with drybone breakage attributes (Villa \& Mahieu 1991; Whittle \& Wysocki 1998). There is one exception: a left ulna shaft (in the Maidstone archive) which displays a typical green-bone/peri-mortem fracture.

There is no evidence of sub-aerial type weathering modifications (Lyman 1994) that could indicate longterm post-mortem exposure, but many elements are lightly or moderately root-etched. Several limb shafts display rodent gnawing marks with unpatinated exposed cortical bone which are likely to be of relatively recent origin. Bennett (1913) records the presence of animal runs and burrows within the precincts of the burial chamber and numerous bones of burrowing animals were recovered during his excavation.

\section{Pathology and cut-marked specimens}

The Coldrum assemblage includes very notable anthropogenic modifications. Three skulls with evidence of cranial trauma indicative of interpersonal violence have been reported elsewhere (Schulting \& Wysocki 2005, 113-14); a probable female adult (Eu.1.5.120) had an unhealed injury to the left frontal and cut-marks on the left temporal bone, an unhealed fracture of the left frontal was present on an adult of indeterminate sex (No. 8), and a second probable female adult (Eu.1.5.125) exhibited a healed depressed fracture of the right frontal.

A total of 522 post-cranial elements were analysed for stone tool cut-marks following the methods of Shipman and Rose (1983), Eickhoff and Herrmann (1985), Olsen and Shipman (1988), and Lyman (1994, 297-9). Samples were inspected macroscopically and by hand lens $(\times 10)$ under oblique light. Selected specimens were inspected using a light microscope and scanning electron microscope (SEM).

Cut-marks were identified on four post-cranial skeletal elements, on two proximal femur fragments a left element (CMF1) and a right element (CMF2), both broken just inferior to the lesser trochanter 


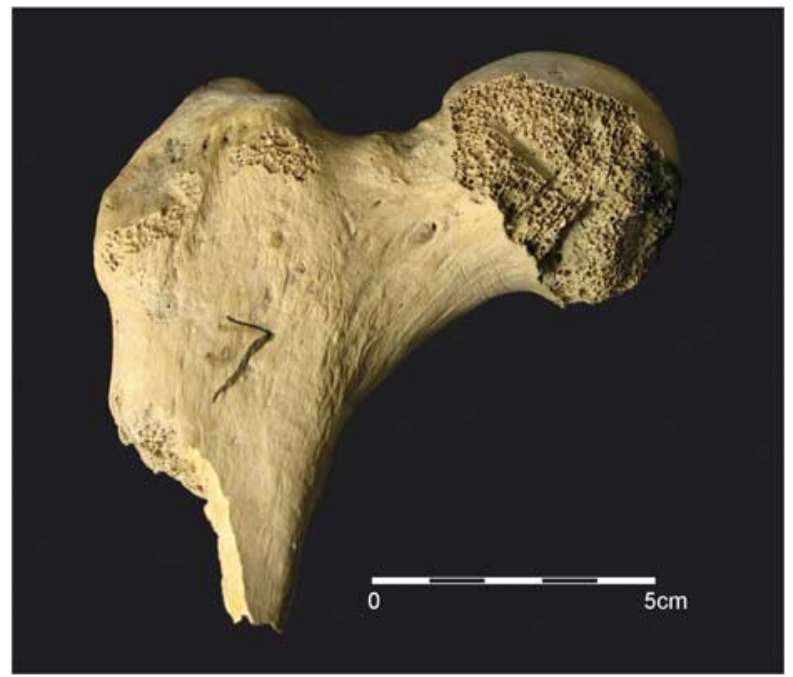

Fig. 4.

Cut-marked right proximal femur fragment (CMF2) from Coldrum

(Fig. 4) - and on a left innominate (CMI1) (Fig. 5), and a right innominate (CMI2).

CMF1 and CMF2 are identified as possibly male based on metric analysis. CMI1 was identified as male based on a sciatic notch-acetabular index of 81.98 (Kelly 1979). The cut-marked right innominate (CMI2) could not be sexed. The elements could represent four separate individuals, but could also represent the remains of a single adult male of moderate stature. They do not pair convincingly with other surviving adult hip-joint bones.

On CMI1 three short, transverse, notch-like incisions are evident at the remnant of the superior ramus of the pubis anterior to the iliopubic eminence.

On CMI2 two notch-like incisions are located at the anterior inferior iliac spine. There are numerous thin, linear, parallel and sub-parallel scratch marks located at the internal posterior iliac fossa, near the margin of the auricular surface, superior to the arcuate line (Fig. 6). These incisions are very similar to those displayed on the anterior surface of the neck of CMF2.

On CMF1 eight short, deep, tightly grouped, $\mathrm{V}$-shaped and patinated transverse parallel incisions are located medially at the inferio-anterior border of the femoral neck marginal to the femoral head.

On CMF2 six deep, tightly grouped, short, parallel incisions are located medially at the inferior surface of the neck. The incisions exhibit V-shaped profiles, patinated inner surfaces and run transversely (posterioanterior orientation) to the long axis of the neck. Under hand lens and oblique light, faint striae are visible at the base of the incisions. The posterior surface of the femoral neck displays some 14 deep, parallel and sub-parallel fine linear incisions at the approximate medio-lateral mid-point of the neck. The incisions are transversal and oblique, orientated superio-inferiorly to the long axis of the neck. The specimen also exhibits a roughly circular area of black, charred bone (c. 15 by $13 \mathrm{~mm}$ ) on the articular surface of the head, anterior to the foveal margin (Fig. 4). The charring is relatively superficial, affecting 2-3 $\mathrm{mm}$ of the underlying trabecular bone.

The thin, linear, scratch-like incisions on CMF2 and CMI2 are very fine and almost invisible under direct light. They are truncated in places by root etchings, pre-date excavation and are almost certainly ancient. Under the SEM micro-striations observed inside the incisions indicate that they were made with a stone implement.

The cut-marks at the medial inferior neck in both femora are deep, purposeful, tightly grouped and isolated, and exhibit bilateral repetition of anatomical placement. Their location suggests that the cutting tool was applied to the capsule attachment of the hip joint at the area of the zona orbicularis where the iliofemoral and pubofemoral ligaments overlap. The slight anterior bias of the cut-marks may indicate that the corpse (or articulated skeleton) was laid on its back. The grouping of fine cut-marks on the anterior neck of the right femur suggests rapid slicing or slashing at the iliofemoral ligament.

The cut-marks suggest dismemberment and dissection of ligaments following partial decomposition or removal of other soft tissues (cf. White 2000, 422, fig. 19.2). If the corpse was still fleshed or partially fleshed, the cuts could have severed the pectineus and iliacus muscles (among others) in order to separate the upper thigh from the hip.

On CMI2, two notch-like cut-marks are located approximately at the attachment site of the iliofemoral ligament and the tendon of the rectus femoris muscle. Multiple, fine cut-marks on the internal surface of the iliac fossa are located at the ventral attachment sites of the iliolumbar and sacroiliac ligaments. On CMI1 the cut-marks relate most closely to the attachment areas of the pectineal and pubofemoral ligaments. 


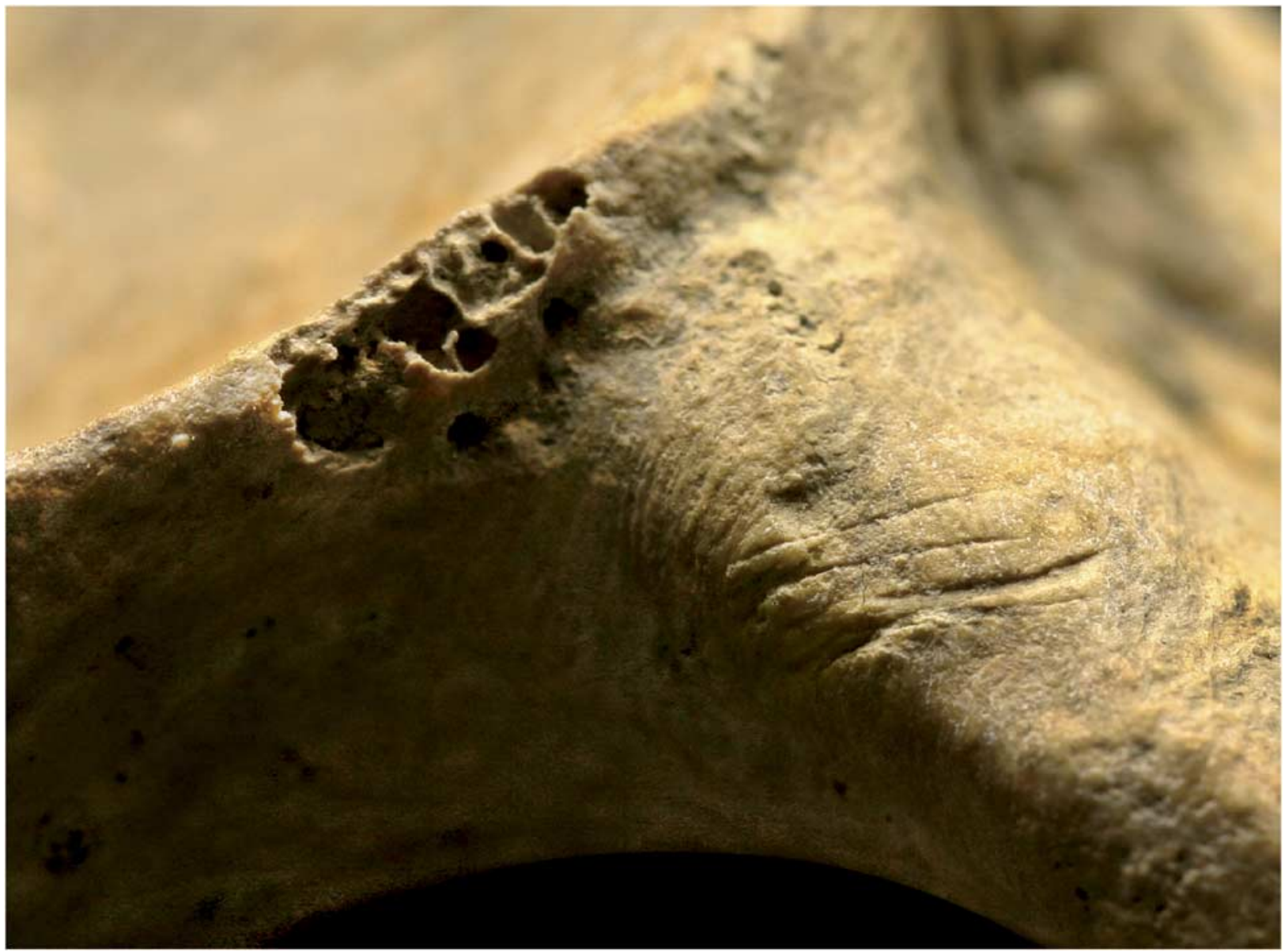

Fig. 5 .

A detail of the cut-marked left innominate (CMI1) from Coldrum

The cut-marks are discretely and precisely located; they do not suggest frenzied hacking or mutilation. Dismemberment at the hip joint of a fleshed or relatively fresh human corpse would result in additional modifications to underlying bone. The absence of incisions at any of the major muscle attachment sites, or at the acetabular rim, may suggest that these elements were already partially skeletonised when dismembered.

\section{Cut-marked early Neolithic human remains}

The Coldrum cut-marked human bone assemblage (two femora, two innominates, and one cranium) is the largest exhibiting peri-mortem dismemberment so far reported from a southern British Neolithic long barrow. Other Neolithic cut-marked human bones (cf. Smith \& Brickley 2009, table 4, 49) comprise an adult clavicle each from West Tump (Smith \& Brickley 2004) and Eyford (Rolleston 1876), an adult rib fragment and an immature femur and humerus from Adlestrop (Smith \& Brickley 2009, 49-51), an adult humerus from Haddenham (Lee \& Wakely 2006), and 23 human bone fragments from Hambledon Hill (McKinley 2008). Many of the Hambledon Hill incisions appear to relate to the process of defleshing, whereas the cut-marks on bones from chambered tombs and barrows are much more indicative of dismemberment and decapitation (Smith \& Brickley 2009, 49-51). The cut-marks on the Haddenham humerus were distributed at the attachment areas of the brachialis and the medial head of the triceps (Lee \& Wakely 2006, 148), and were interpreted as indicative of the defleshing of these muscles from the bone. 


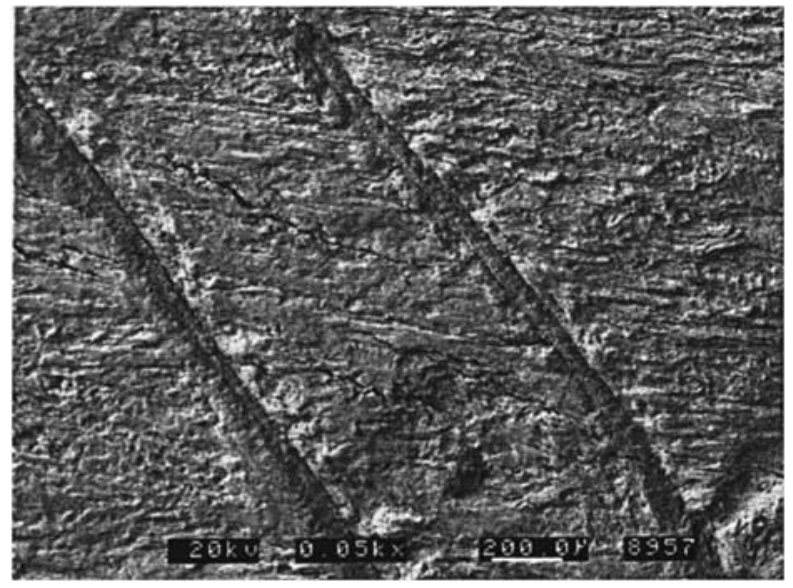

Fig. 6.

SEM image of fine linear incisions on innominate CMI2, displaying stone tool characteristics, V-shaped profile, and multiple fine striae. (Photograph: Y.F-J)

The Coldrum, West Trump, Eyford, Aldestrop, and Haddenham incised bones can be located within the wider spectrum of corpse manipulation practices which occurred at Neolithic monuments (Smith \& Brickley 2009, 51). Skulls may be separated from post-cranial remains and bones from several individuals may be found stacked or arranged in discrete groups (e.g. Wysocki et al. 2007; Savory 1956; Keiller \& Piggott 1938). Such arrangements have been interpreted as evidence of secondary burial following exposure or excarnation. Alternatively such evidence may represent decomposition of fleshed in situ interments with subsequent rearrangement. Both processes may have taken place at different monuments, or at the same monument (Saville 1990; Whittle \& Wysocki 1998; Bayliss \& Whittle 2007; Smith \& Brickley 2009). In any case, stacking, rearrangement, separation, and possibly transportation imply the availability of disarticulated material. Soft tissue decomposition and subsequent disarticulation take place over variable timescales, largely dependent on ambient temperature, cooler conditions needing more time (Megyesi et al. 2005), while articulation of the hip and thigh bone may persist long after other connective tissues and joints have decomposed and separated (Haglund 1997). In such contexts dismemberment may be required to hasten or finalise the process.

Necrophagy, shamanism, witchcraft, or other forms of natural magic could also be implied, and the borders between such activities, ancestor worship, treatment of the dead, and other practices may have been indistinct. Criteria diagnostic of cannibalism, such as percussion marks, impact notches and microflakes, green-bone fracture attributes, and potpolishing were not observed at Coldrum (cf. Villa et al. 1986; Villa \& Mahieu 1991; White 1992; Turner \& Turner 1999; Boulestin et al. 2009).

\section{THE AGE OF THE HUMAN REMAINS: RADIOCARBON DATING}

Radiocarbon measurements were made at the Oxford Radiocarbon Accelerator Unit (ORAU). An initial set of results was withdrawn following identification of a technical problem with sample processing (Bronk Ramsey et al. 2004a; Bayliss et al. 2007a). A second round produced 27 radiocarbon measurements, on re-ultrafiltered excess collagen from original samples (Bronk Ramsey et al. 2004a), and on new samples from elements used for the MNI, the four skulls associated with the upper and lower platforms, and incised elements (Table 1). The new samples were processed using the revised gelatinisation and ultrafiltration technique (Bronk Ramsey et al. 2004b; Brock et al. 2007; 2010), graphitised (Dee \& Bronk Ramsey 2000), and measured by accelerator mass spectrometry (AMS) (Bronk Ramsey et al. 2004b).

\section{Stable isotope considerations for radiocarbon dating}

The results from the stable isotope analysis do not indicate a clear marine or freshwater reservoir effect (Schoeninger et al. 1983; see below). However, there is an enrichment, which warrants brief discussion here (and further below). There is an obvious correlation between radiocarbon date and both $\delta^{13} \mathrm{C}$ and $\delta^{15} \mathrm{~N}$ values. The $\delta^{15} \mathrm{~N}$ values are unusually high for Britain, but the absence of faunal data from the site makes it impossible to identify the herbivore to human enrichment. The $\delta^{15} \mathrm{~N}$ values raise the possibility of a freshwater reservoir effect, though enrichment could be attributed to alternative causes (see below). Freshwater offsets are highly system-specific (Keaveney \& Reimer 2012), depending on: groundwater; inorganic and organic water body geochemistry; relative contributions of submergent and emergent photosynthetic producers; and relative contributions of aquatic and terrestrially produced protein to human diet.

The slopes of $\delta^{15} \mathrm{~N}$ and $\delta^{13} \mathrm{C}$ against time (Figs 11-12, below) show a correlation in the opposite direction 
TABLE 1: RADIOCARBON AND STABLE CARBON AND NITROGEN RESULTS FROM THE COLDRUM HUMAN REMAINS

\begin{tabular}{|c|c|c|c|c|c|c|c|}
\hline$\overline{L a b . ~ c o d e}$ & Skeletal element & $\begin{array}{l}\text { ORAU }{ }^{1} \text { chemistry } \\
\text { code }\end{array}$ & $\begin{array}{l}\text { Radiocarbon age } \\
\text { (BP) }\end{array}$ & $\delta^{13} \mathrm{C}$ & $\delta^{15} N$ & $\begin{array}{l}\text { Calibrated date range } \\
(95 \% \text { confidence; cal BC) }\end{array}$ & $\begin{array}{l}\text { Posterior density estimate } \\
\text { (model 2; } 95 \% \text { probability; } \\
\text { cal BC) }\end{array}$ \\
\hline OxA-13733 & LF1; left femur & $\mathrm{AF}$ & $5076 \pm 36$ & -20.89 & 9.64 & $3970-3780$ & $3950-3790$ \\
\hline OxA-13734 & LF2; left femur & $\mathrm{AF}$ & $5088 \pm 31$ & -20.41 & 8.77 & $3970-3790$ & $3950-3790$ \\
\hline OxA-13718 & LF3; left femur & (Re AF, NRC) & $5089 \pm 38$ & -21.29 & 11.66 & (Weighted mean $5043 \pm 25$ & $3940-3790$ \\
\hline OxA-13735 & & $\mathrm{AF}$ & $5012 \pm 31$ & -20.43 & 10.41 & $\begin{array}{l}\mathrm{T}^{\prime}=2.5 ; \mathrm{T}^{\prime} 5 \%=3.8 ; \mathrm{v}=1 \\
\text { Ward \& Wilson } 1978 \text { ) }\end{array}$ & \\
\hline & & & & & & $3950-3770$ & \\
\hline OxA-13736 & LF4; left femur & $\mathrm{AF}$ & $4672 \pm 31$ & -21.35 & 10.4 & $3530-3360$ & $3530-3360$ \\
\hline OxA-13737 & LF5; left femur & $\mathrm{AF}$ & $5006 \pm 34$ & -20.4 & 9.75 & $3950-3700$ & $3940-3770$ \\
\hline OxA-13719 & LF6; left femur & (Re AF, NRC) & $4599 \pm 38$ & -20.62 & 9.9 & (Weighted mean $4619 \pm 24$ & $3500-3430(66 \%)$ or \\
\hline OxA-13738 & & $\mathrm{AF}$ & $4632 \pm 30$ & -21.23 & 11.63 & $\begin{array}{l}\text { T'=0.5; T'5\% } \% 3.8 ; \mathrm{v}=1 ; \\
\text { Ward \& Wilson 1978) } \\
3500-3350\end{array}$ & $3380-3350(29 \%)$ \\
\hline OxA-13739 & LF7; left femur & $\mathrm{AF}$ & $5027 \pm 31$ & -20.63 & 9.89 & $3950-3710$ & $3940-3780$ \\
\hline OxA-13740 & LF8; left femur & $\mathrm{AF}$ & $5041 \pm 32$ & -20.60 & 10.34 & $3960-3710$ & $3940-3790$ \\
\hline OxA-13720 & LF9; left femur & (Re AF, NRC) & $4709 \pm 37$ & -21.02 & 10.69 & (Weighted mean $4757 \pm 23$; & $3640-3510$ (90\%) \\
\hline OxA-13741 & & $\mathrm{AF}$ & $4786 \pm 29$ & -21.22 & 10.14 & $\begin{array}{l}\mathrm{T}^{\prime}=2.7 ; \mathrm{T}^{\prime} 5 \%=3.8 ; \mathrm{v}=1 ; \\
\text { Ward \& Wilson 1978) } \\
3740-3380\end{array}$ & \\
\hline OxA-13742 & LF10; left femur & $\mathrm{AF}$ & $4832 \pm 31$ & -20.91 & 9.78 & $3660-3540$ & $3660-3620(18 \%)$ or \\
\hline OxA-13721 & LF11; left femur & (Re AF, NRC) & $5000 \pm 38$ & -20.61 & 9.25 & (Weighted mean $5045 \pm 24$; & $3590-3520(78 \%)$ \\
\hline OxA-13743 & & $\mathrm{AF}$ & $5072 \pm 30$ & -20.7 & 9.95 & $\begin{array}{l}\mathrm{T}^{\prime}=2.2 ; \mathrm{T}^{\prime} 5 \%=3.8 ; \mathrm{v}=1 ; \\
\text { Ward \& Wilson 1978) } \\
3950-3770\end{array}$ & $3940-3790$ \\
\hline OxA-13744 & RF12; right femur & $\mathrm{AF}$ & $4784 \pm 31$ & -20.4 & 10.25 & $3650-3520$ & $3650-3510$ \\
\hline OxA-13745 & RF13; right femur & $\mathrm{AF}$ & $4792 \pm 30$ & -20.69 & 11.25 & $3650-3520$ & $3650-3510$ \\
\hline OxA-13746 & LF14; left femur & $\mathrm{AF}$ & $4483 \pm 30$ & -20.92 & 11.54 & $3350-3020$ & $3360-3150$ \\
\hline OxA-13747 & LF15; left femur & $\mathrm{AF}$ & $4420 \pm 31$ & -21.37 & 11.62 & $3320-2920$ & $\begin{array}{l}3340-3210(87 \%) \text { or } \\
3180-3160(1 \%) \text { or } \\
3110-3030(7 \%) \\
\text { Poor individual agreement } \\
\text { index }(\mathrm{A}=47 \%)\end{array}$ \\
\hline OxA-13748 & LF16; left femur & $\mathrm{AF}$ & $4503 \pm 31$ & -20.99 & 11.05 & $3360-3090$ & $3360-3150$ \\
\hline OxA-13749 & $\begin{array}{l}\text { CMF1; cut-marked femur 1. ??male } \\
\text { (metric analysis) }\end{array}$ & $\mathrm{AF}$ & $4664 \pm 30$ & -20.68 & 10.42 & $3630-3360$ & $3520-3360$ \\
\hline OxA-13750 & $\begin{array}{l}\text { CMF2; cut-marked femur 2. ??male } \\
\text { (metric analysis) }\end{array}$ & $\mathrm{AF}$ & $4670 \pm 31$ & -20.82 & 10.59 & $3630-3360$ & $3530-3360$ \\
\hline OxA-13751 & $\begin{array}{l}\text { CMI1; cut-marked innominate } 1 \text {. } \\
\text { male (sciatic notch-acetabular index } \\
\text { of } 81.98 \text {; Kelley 1979) }\end{array}$ & $\mathrm{AF}$ & $4639 \pm 30$ & -20.79 & 10.43 & $3520-3350$ & $3520-3350$ \\
\hline OxA-16039 & $\begin{array}{l}\text { Eu.1.5.120; skull (with } 2 \text { perimortem } \\
\text { cranial injuries \& cut-marks) from } \\
\text { lower level }\end{array}$ & $\mathrm{AF}$ & $5101 \pm 39$ & -20.6 & 10 & $3980-3790$ & $3950-3790$ \\
\hline OxA-16040 & Eu. 1.5.123; skull from lower level & $\mathrm{AF}$ & $5077 \pm 38$ & -20.7 & 10.2 & $3970-3770$ & $3950-3790$ \\
\hline
\end{tabular}


M. Wysocki et al. DATES, DIET, \& DISMEMBERMENT: COLDRUM MEGALITHIC MONUMENT, KENT

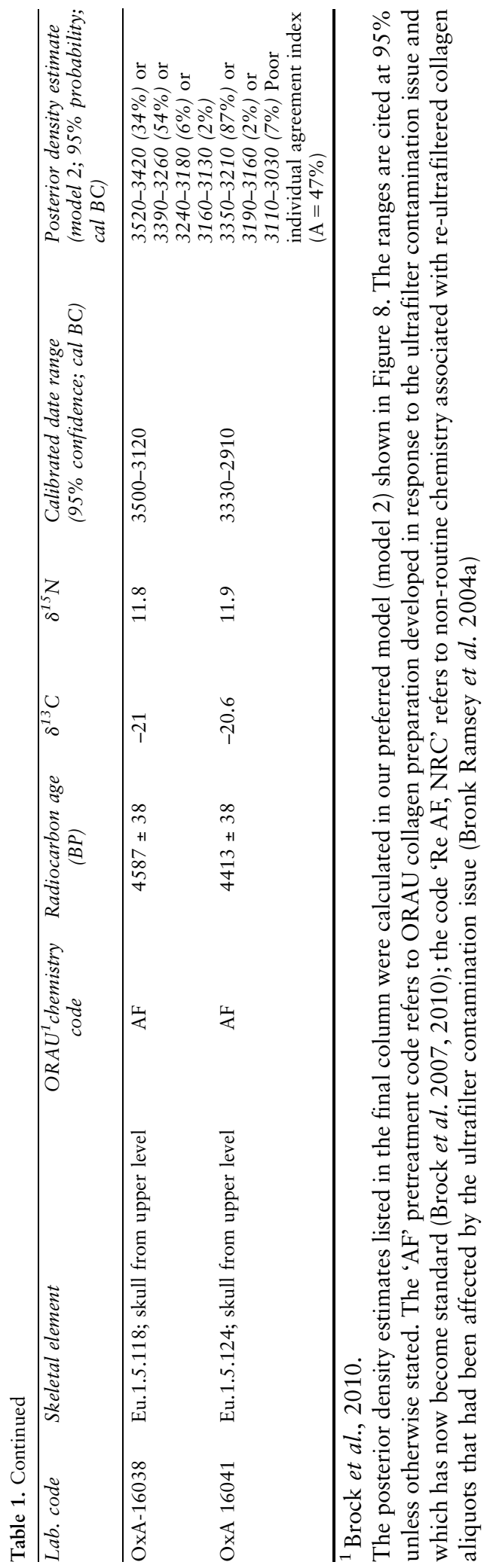

for either an increased fresh or marine fish consumption effect (most markedly in the $\delta^{15} \mathrm{~N}$ patterning; Fig. 11). If either a directional trend over time in a marine or a freshwater reservoir were to be invoked, a trend in higher fish consumption (i.e. from a ${ }^{14} \mathrm{C}$ depleted source) would lead to a higher collagen $\delta^{15} \mathrm{~N}$ value over time. This trend over time does not preclude aquatic sources in the diet, though it does mean that the overall spread in ${ }^{14} \mathrm{C}$ dates cannot entirely be explained in this way.

From the $\delta^{15} \mathrm{~N}$ values it seems unlikely that there is a significant offset, but an effect (for example of $<100$ radiocarbon years, which would have a variable effect on the calibrated calendar years across the population as a whole) cannot be ruled out. Importantly those samples more likely to be affected are those with higher $\delta^{15} \mathrm{~N}$ values, and the highest $\delta^{15} \mathrm{~N}$ values are greatest in the latest radiocarbon results. The implications are that any freshwater fish offset effective on the earliest data is likely to be relatively small (see below). This said, there is potential that the resultant 'real' spread of dates would be greater (i.e. the duration of activity at the site), and that the estimate for the end of activity at the site could be later. We have presented the data as if there are no diet-derived offsets. Given the importance of the chronology of the site in Neolithic studies, this should be the subject of further research.

\section{Calibration of the radiocarbon dates}

The results reported are conventional radiocarbon ages (Stuiver \& Polach 1977). Date ranges in Table 1 have been calculated by the maximum intercept method (Stuiver \& Reimer 1986). Distributions in figures have been calculated using the probability method of Stuiver and Reimer (1993). Measurements have been calibrated using IntCal09 (Reimer et al. 2009) and OxCal v4.1 (Bronk Ramsey 1995; 1998; 2001; 2009).

\section{Bayesian modelling}

Bayesian chronological modelling combines calibrated radiocarbon dates with archaeological prior information (Buck et al. 1991; 1992; 1996; Bronk Ramsey 1995; 1998; 2001; 2009). This process accounts for statistical scatter inherent in an assemblage of dates, and can produce more precise posterior density estimates from extant radiocarbon likelihoods. Bayesian modelling has been applied using OxCal v4.1, 
which uses a form of Markov Chain Monte Carlo (MCMC) sampling and implements the MetropolisHastings algorithm. Bronk Ramsey (2009) details the algorithm and program construction; the algorithms used in these models can be derived from the structure shown in the figures and the Command Query Language 2 (CQL2) keywords (ibid.). Posterior density estimates are quoted in italics. Ranges are quoted following recommendations by Stuiver and Polach (1977) and rounded outwards by 10 years.

\section{Sample association}

None of the results actually dates the construction of the monument. It is possible that there was some interval between the deaths of the individuals and the monument construction (Wysocki et al. 2007, 77), sufficient at least for the defleshing and corpse manipulation outlined above. However, given that the dated elements show no evidence for exposure, we suggest that the remains were deposited relatively soon after death, not as part of significantly later secondary burial.

\section{Model construction}

There is relatively limited 'informative' prior information with which to constrain the radiocarbon data (Bayliss et al. 2007a); four skulls can be identified as originating from Bennett's upper and lower levels. We present three scenarios that reflect different readings of the available evidence. Model 1 uses the known relationships between the four skulls, and analyses the other data using the interpretation that they are a random sample from a uniformly distributed phase of activity (Buck et al. 1992). We will argue that this model probably importantly under-constrains the associated statistical scatter (ibid.). Model 3 postulates four phases of activity, derived from the statistical consistency of the radiocarbon dates, and archaeological indications that activity at the site was episodic. Model 3 probably over-interprets the available evidence (cf. Steier \& Rom 2000).

Our preferred interpretation is model 2, which is probably not significantly misleading (cf. Box 1979; Bayliss et al. 2007a). This model uses the available stratigraphic information and the statistical coherence of early measurements. Model 2 is supported by the trend in stable isotope evidence (see below), but the attribution of radiocarbon results to phases is necessarily interpretive because of the uncertainty regarding the recovery contexts of most samples. Model 2 has been introduced in Bayliss et al. (2011a); this paper fully details the chronological analysis of the site and relates the data to the isotope measurements (see below). It is important to emphasise that assigning dates to phases based on the dates themselves has the potential to reify or over-interpret data; we do not do this here - we base our preferred interpretation on the available prior information (the stratigraphy, records of the site excavation, and the stable isotope data) and we demonstrate (through sensitivity analysis) that our preferred model is probably not significantly misleading.

\section{MODEL 1}

Measurements OxA-16039 and OxA-16040 were produced on two crania from the lower 'platform', with OxA-16038 and OxA-16041 produced on two crania from the upper 'platform'.

The lower level skull results are statistically consistent (OxA-16040; -16039; T' $=0.2$; T'5\% $=3.8 ; v=1$; Ward \& Wilson 1978); these individuals could have died at the same point in time. The upper level crania results are not statistically consistent $\left(\mathrm{T}^{\prime}=10.5\right.$; T' $5 \%=3.8 ; v=1$; ibid. $)$. The lower level results are earlier than those from the upper level (Table 1), and could support Bennett's interpretation that the lower 'platform' was an earlier in situ Neolithic deposit that underlay the younger upper 'platform' (though see above).

Model 1 has good agreement $\left(\mathrm{A}_{\text {overall }}=78 \%\right)$, and estimates that activity began in $4060-3870 \mathrm{cal}$ BC $(95 \%$ probable $)$ or $3990-3910$ cal BC $(68 \%$ probable; start Bennett model 1; Fig. 7), with the end of activity in 3310-2970 cal BC (95\% probable) or 3290-3140 cal BC (68\% probable; end Bennett model 1; Fig. 7). In our view the analyses outlined in models 2 and 3 , with the evidence that other skeletal remains were recovered from the lower 'platform' (Bennett 1913), suggest that activity in the tomb may not have been continuous and so model 1 is not the most appropriate.

MODEL 2

Model 2 divides the data into two phases. The model employs Bennett's (1913) observed stratigraphic relationships, and attributes other measurements to these phases based on their radiocarbon ages.

Model 2 has good agreement $\left(\mathrm{A}_{\text {overall }}=75 \%\right)$. The data included in phase 1 (Fig. 8) have been selected because they are statistically consistent (OxA-16039; -16040; -13733; $-13734 ;-13718 ;-13735 ; 13737 ;-13739 ;-13740 ;-13721$; -13743; T' $=11.3 ; T^{\prime} 5 \%=18.3 ; v=10 ;$ Ward \& Wilson 1978). These measurements could represent a single archaeological 'event', with for example all the individuals dying on the same day in the second half of the 40th or 39th century cal BC (the weighted mean is $5052 \pm 11 \mathrm{BP}$ ). Perhaps a more convincing scenario is that the remains represent a 
M. Wysocki et al. DATES, DIET, \& DISMEMBERMENT: COLDRUM MEGALITHIC MONUMENT, KENT

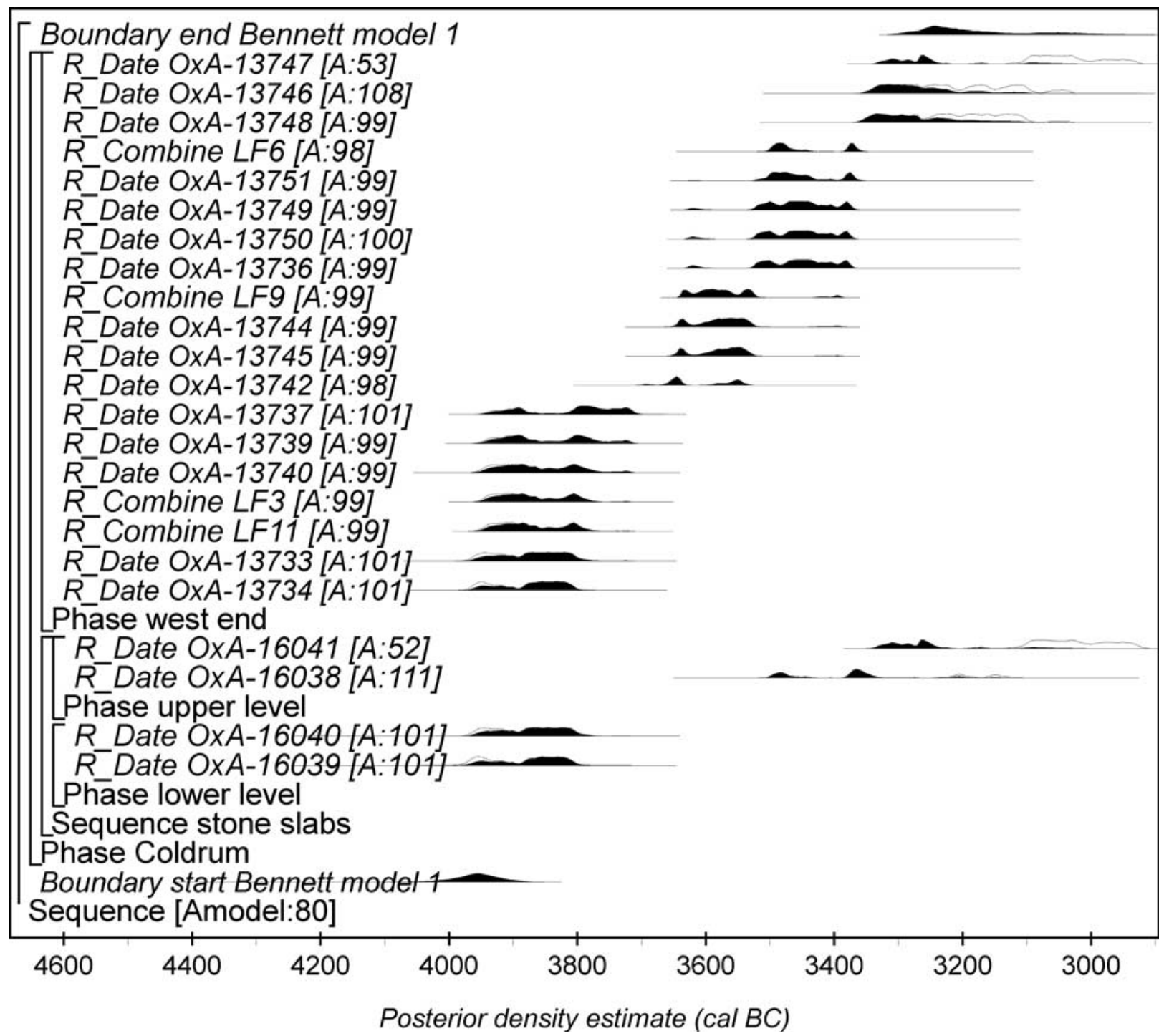

Fig. 7.

Model 1. The brackets and OxCal v4.1 CQL2 keywords define the model structure (Bronk Ramsey 2009). We argue that the model probably under-constrains the radiocarbon dates from Coldrum (see main text and Fig. 8)

population who died over a short duration of time. We suggest that this 'phase' could represent a discrete and early period of deposition, more or less contemporary with the construction of the monument. An alternative view - given that we cannot estimate the date of monument construction is that these results represent remains that were significantly old at their time of deposition; we think that this is implausible.

From model 2, Neolithic activity at Coldrum began in 3980-3800 cal BC (95\% probable) or 3960-3880 cal BC (68\% probable; start Coldrum 1 model 2; Fig. 8). This phase ended in 3930-3750 cal BC $(95 \%$ probable $)$ or 3910-3775 cal BC (68\% probable; end Coldrum 1 model 2;
Fig. 8), and lasted for $0-140$ years (95\% probable) or $0-80$ years (68\% probable; DurationPhase1; Fig. 9).

After an interval of 60-350 years (95\% probable) or 140-290 years (68\% probable; Coldrum 1/2; Fig. 9), further individuals died and their remains were placed in the chamber. The postulated subsequent phase began in $3730-3540 \mathrm{cal} \mathrm{BC}(95 \%$ probable) or 3670-3560 cal BC (68\% probable; start Coldrum 2 model 2; Fig. 8), and ended in 3310-2980 cal BC (95\% probable) or 3300-3170 cal BC (68\% probable; end Coldrum 2 model 2; Fig. 8). The renewed use of the chamber lasted for 240-590 years $(95 \%$ probable) or $270-410$ years $(68 \%$ probable; DurationPhase2; Fig. 9). Given the long duration of 'phase 2' as 


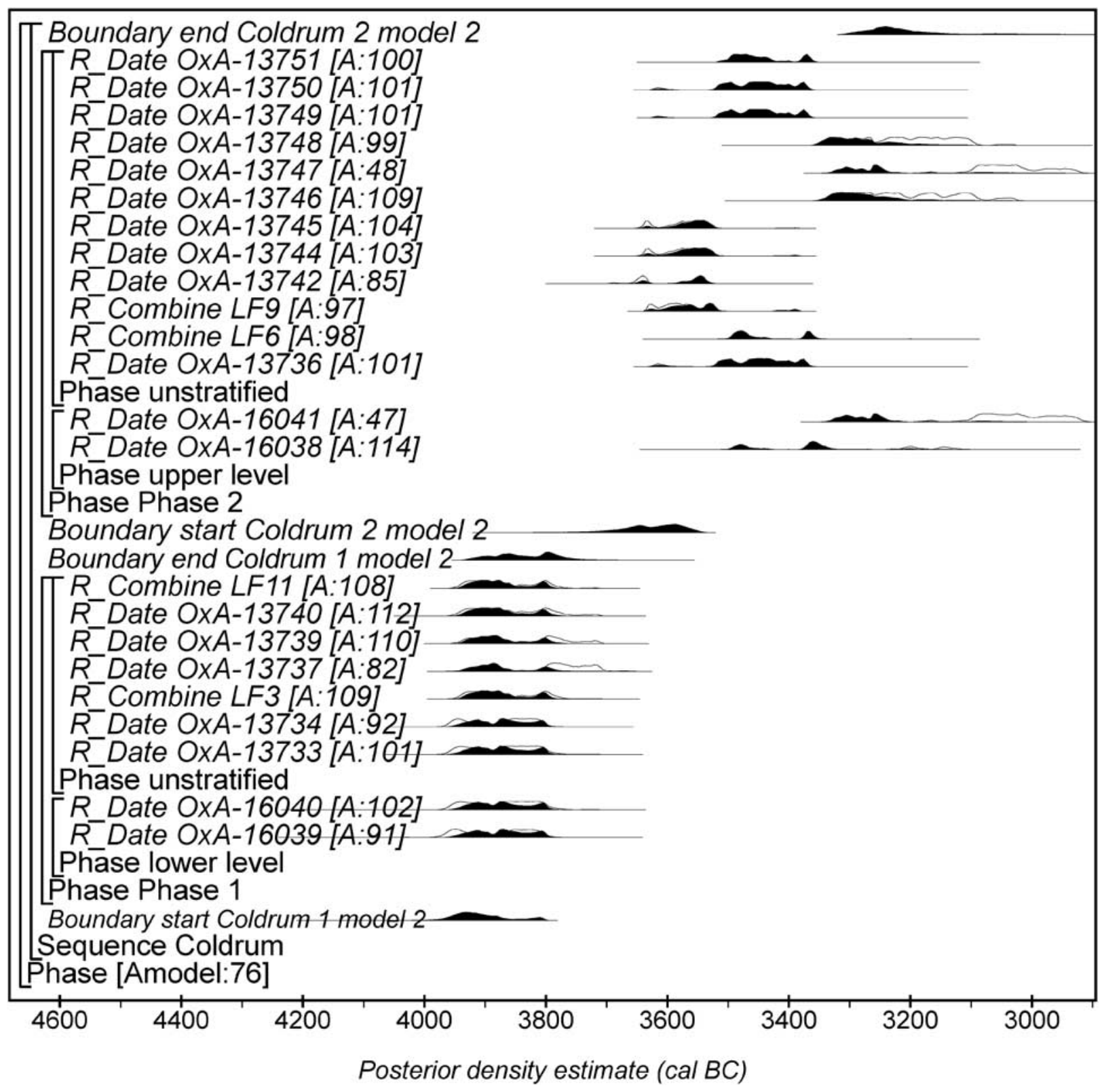

Fig. 8 .

Model 2, the preferred model of the radiocarbon dates from Coldrum. The format is the same as in Figure 7. This model is a more interpretive treatment than that shown in Figure 7, but we argue that it is a more satisfactory treatment of the data

presented here, it seems possible that this activity might mask more taphonomically complex processes, and might lump together several discrete 'phases'. We investigate this possibility further in model 3.

\section{MODEL 3}

Model 3 presents the dates in four phases; the first is the same as in model 2, while the others explore the later use of the monument. This model reflects the observations of Bennett (1913) that discrete bone deposits may indicate episodic activity.

In addition to the statistically consistent radiocarbon dates from phase 1 , results from a second suggested phase are statistically consistent (OxA-13742; -13745; -13744; $-13741 ;-13720 ; \mathrm{T}=6.5 ; \mathrm{T}, 5 \%=9.5 ; v=4$; Ward \& Wilson $1978)$, as are those from a third phase (OxA-13736; -13750 ; 


\section{Interval Coldrum 1/2}

\section{Span DurationPhase1}

\section{Span DurationPhase2}

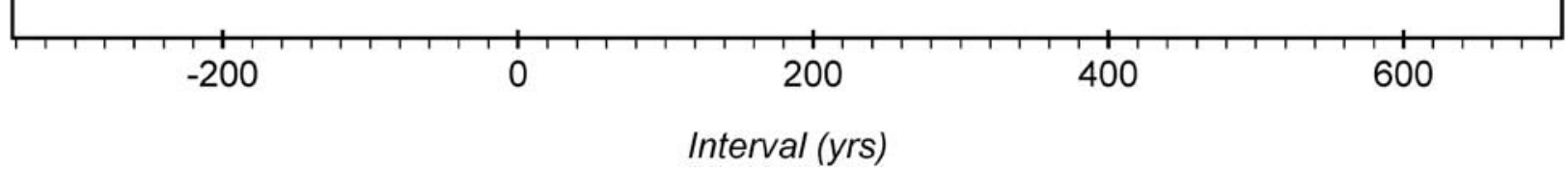

Fig. 9.

Probability distributions derived from our preferred model (model 2; Fig. 8) estimating the duration of activity associated with each of the phases shown in the model in Figure 8, and the interval between the two phases

$-13749 ;-13751 ;-13719 ;-13738 ; \mathrm{T}=3.4 ;$ T'5\% $=11.1 ;$ $v=5$; ibid.). The remaining latest data contain measurements that are not statistically consistent (OxA-16038; $-13748 ;-16041 ;-13746 ;-13747 ; \mathrm{T}=15.4 ; \mathrm{T} 5 \%=9.5$; $v=4$; ibid.). It is possible that 'missing' material excavated from the chamber represented activity within the hiatuses that are postulated here. We feel a scenario that includes discrete phases of activity is preferable, but cannot entirely exclude the possibility that continual deposition of the dead occurred at the site.

Model 3 has good overall agreement $\left(\mathrm{A}_{\text {overall }}=82 \%\right)$. The first phase began in 3980-3800 cal BC (95\% probable) or 3960-3870 cal BC (63\% probable; start phase 1 model 3; Fig. 10), and ended in 3930-3750 cal BC (95\% probable) or 3900-3770 cal BC (68\% probable; end phase 1 model 3; Fig. 10). Phase 2 began in 3720-3530 cal BC (95\% probable) or 3660-3630 cal BC (14\% probable) or 3610-3540 cal BC (54\% probable; start phase 2 model 3; Fig. 10), and ended in 3590-3480 cal BC (92\% probable) or 3570-3510 cal BC (68\% probable; end phase 2 model 3; Fig. 10). Phase 3 began in 3540-3430 cal BC (94\% probable) or 3520-3460 cal BC (68\% probable; start phase 3 model 3; Fig. 10), and ended in 3500-3340 cal BC (95\% probable) or 3480-3400 cal BC (68\% probable; end phase 3 model 3; Fig. 10). Phase 4 began in 3430-3140 cal BC (95\% probable) or 3390-3250 cal BC (68\% probable; start phase 4 model 3; Fig. 10), and ended in 3330-2920 cal BC (95\% probable) or 3320-3180 cal BC $(44 \%$ probable $)$ or $3090-3000$ cal BC $(24 \%$ probable; end phase 4 model 3; Fig. 10).

Comparison of the chronological models for Coldrum All Bayesian models are inherently limited representations of reality (Buck et al. 1996). Model 1 is the most conservative and the radiocarbon dates are least constrained by it. Both model 2 and 3 are more satisfactory than model 1 in archaeological terms
(Bennett recovered an assemblage from the lower level), and mathematical terms (because the data are probably insufficiently constrained in model 1). We prefer model 2 because, while episodic activity at the site seems entirely feasible, the level of detail available from the site archive is not sufficient for more complex modelling.

Why does this discussion of different interpretations matter? The model 1 posterior density start estimate is least precise, and the range extends into the early 41st century cal BC. This impression is important in an early Neolithic where we can now attempt to address change on a generational level (Whittle et al. 2011b). The effect is obvious when model 1 posteriors are compared with estimates from models 2 and 3 (Table 2; Fig. 11). The differences between outputs emphasise the importance of examining date ranges and probability distribution for an estimate. In any case, the key posterior density estimates from models 2 and 3 are very similar (Table 2); if different interpretations of the most appropriate treatment of prior information produce similar outputs, we may be fairly confident that any particular model is not significantly biasing our results and that our preferred solution is robust (Steier and Rom 2000).

\section{STABLE ISOTOPE ANALYSIS}

\section{Stable isotope method}

Collagen was prepared following Privat et al. (2002). Aliquots of 3-4 mg were analysed in triplicate (where 


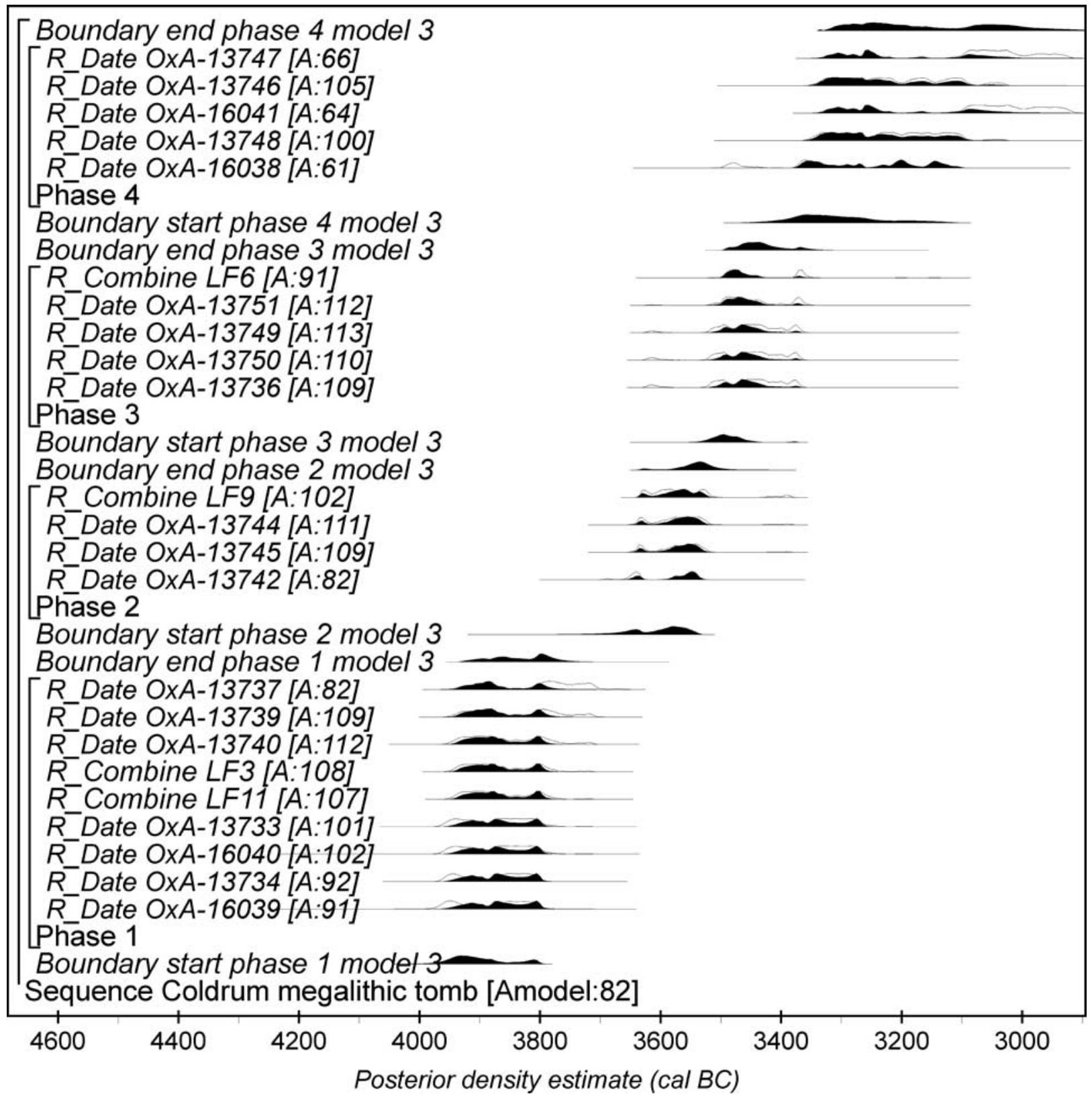

Fig. 10.

Model 3, an alternative model of the radiocarbon dates from Coldrum. The format is the same as in Figure 7 . The model presents results as if they reflected more episodic activity at the site. While this interpretation could be supported by both the radiocarbon dates and archaeological information from the site, we do not think that the archive is sufficiently robust to warrant this additional treatment

possible) or duplicate for each dated skeletal element, and averages taken for analysis. Measurements reported here were made on collagen with good preservation, passing acceptable $\mathrm{C} / \mathrm{N}$ ratio and \% collagen criteria
(Bronk Ramsey et al. 2004a), and reflect in vivo rather than diagenetic signals.

Purified collagen samples were processed in an automated carbon and nitrogen analyser coupled to a 
M. Wysocki et al. DATES, DIET, \& DISMEMBERMENT: COLDRUM MEGALITHIC MONUMENT, KENT

TABLE 2: THE START AND END POSTERIOR DENSITY ESTIMATES FOR THE COLDRUM MONUMENT FROM THE DIFFERENT MODELS PRESENTED IN THE TEXT (FIGS 7, 8, \& 10)

\begin{tabular}{|c|c|c|c|}
\hline Model No. & $\begin{array}{l}\text { Posterior density estimate } \\
\text { name }\end{array}$ & $\begin{array}{l}\text { Posterior density estimate } \\
\text { (cal BC; } 95 \% \text { probable) }\end{array}$ & $\begin{array}{l}\text { Posterior density estimate } \\
\text { (cal BC; } 68 \% \text { probable) }\end{array}$ \\
\hline 1 & start Bennett model 1 & $4060-3870$ & $3990-3910$ \\
\hline 2 (preferred) & start Coldrum 1 model 2 & $3980-3800$ & $3960-3880$ \\
\hline & start phase 1 model 3 & $3980-3800$ & $\begin{array}{l}3960-3870(63 \%) \text { or } \\
3820-3800(5 \%)\end{array}$ \\
\hline 1 & end Bennett model 1 & $3310-2970$ & $3290-3140$ \\
\hline 2 (preferred) & end Coldrum 2 model 2 & $3310-2980$ & $3300-3170$ \\
\hline 3 & end phase 4 model 3 & $3330-2920$ & $\begin{array}{l}3320-3180(44 \%) \text { or } \\
3090-3000(24 \%)\end{array}$ \\
\hline
\end{tabular}

The upper half of the table presents estimates for the start of the earliest activity at the monument. The lower half of the table provides estimates for the end of activity at the monument. Ranges are cited at $95 \%$ or $68 \%$ probability unless otherwise stated

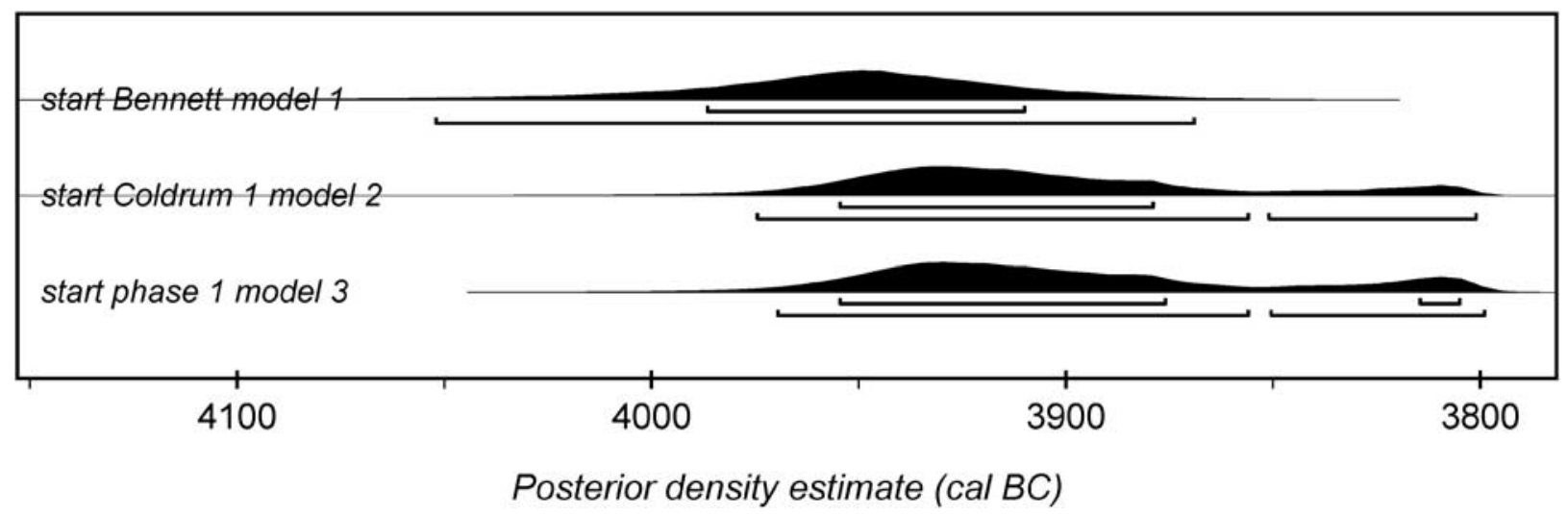

Fig. 11.

Comparison of key posterior density estimates produced from the different interpretations of the most appropriate treatment of the available prior information (Figs 7, 8, and 10). We suggest that the posterior density estimate for the start of Neolithic activity from model 2 represents the most satisfactory treatment of the data. For each posterior density estimate the range at $68 \%$ probability is shown immediately under the distribution, while the lower range is at $95 \%$ probability

continuous-flow isotope ratio-monitoring mass spectrometer (Europa Geo 20/20 mass spectrometer). $\delta^{13} \mathrm{C}$ values were measured relative to secondary standards included in the same run, which had been calibrated to VPDB; $\delta^{15} \mathrm{~N}$ values measured were relative to AIR. The estimated analytical (random) error is $0.3 \%$ for $\delta^{13} \mathrm{C}$ and $0.1 \%$ for $\delta^{15} \mathrm{~N}$.

No individuals sampled here were young enough to retain any 'weaning signal' and juvenile samples (OxA-13747; -13746; -13741; -13742) are consistent with this. No significant difference in $\delta^{15} \mathrm{~N}$ values are observed where sex can be identified, although, given the wide variance, small differences of $c .0 .5 \%$ would be difficult to demonstrate. Unfortunately, there are no contemporary faunal samples from the site, making a reliable evaluation of the trophic level enrichment $\left(\delta^{15} \mathrm{~N}\right)$ impossible.

\section{Stable isotope results}

The $\delta^{13} \mathrm{C}$ values (average $\delta^{13} \mathrm{C}=-20.7 \pm 0.3 \%$ ) easily fit into typical terrestrial C3 human ranges from Neolithic British sites. The variance is similar to intra-site values found across Neolithic Europe (Hedges et al. 2013).

The $\delta^{15} \mathrm{~N}$ data are significant in value and pattern. The dataset (average $\delta^{15} \mathrm{~N}=10.4 \pm 0.8 \%$ ) is high when compared with Neolithic values; excluding Coldrum, Le Déhus (Guernsey), and known young children, the British Neolithic average is $\delta^{15} \mathrm{~N}=9.6$ $\pm 0.8 \%$ (Rick Schulting, pers. comm. 2012; Schulting $\&$ Richards submitted). Le Déhus provides a notable exception; here Schulting et al. (2010b) produced average $\delta{ }^{15} \mathrm{~N}$ values of $14.1 \%$ (see below). The Quanterness average $\delta^{15} \mathrm{~N}$ higher than Coldrum at $11.1 \pm 0.6 \%$, and was not interpreted as evidence of the consumption of marine foods (Schulting et al. 2010a); 


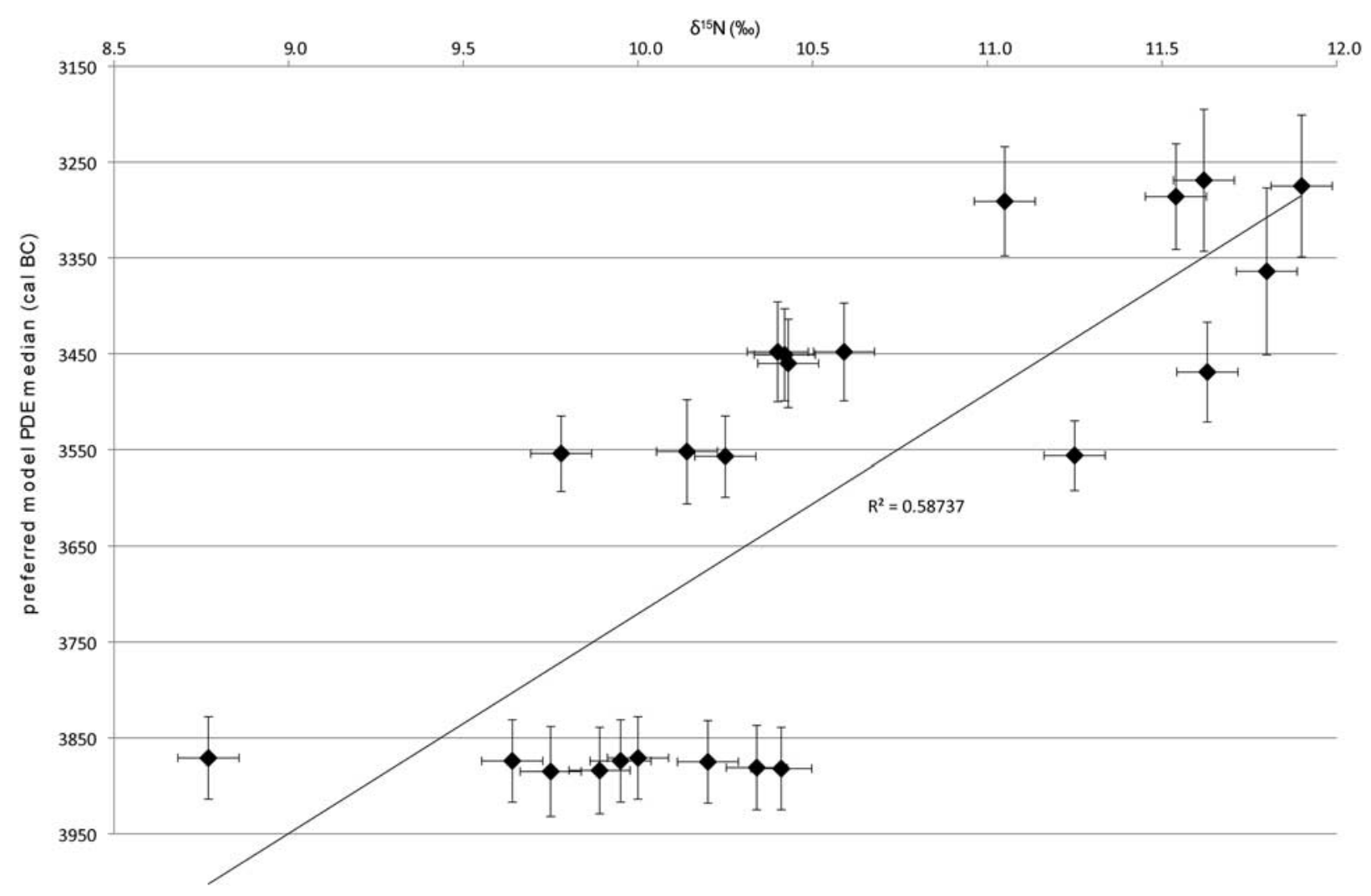

Fig. 12 .

Changes in $\delta^{15} \mathrm{~N}$ values over time. The horizontal axis plots $\delta^{15} \mathrm{~N}$ (with estimated analytical error); the vertical axis plots the posterior density estimate median and standard deviation range from the preferred model (model 2, Fig. 8)

perhaps as at Coldrum, such trends reflect distinct regional traditions after the appearances of the regionally earliest Neolithic traditions and material culture. In addition, the Coldrum $\delta^{15} \mathrm{~N}$ variance is also comparatively large.

\section{Change through time in isotope values}

We have used the median of the $95 \%$ posterior density estimate from the preferred chronological model (model 2) as a means to analyse change through time. The main feature of the data, which may obscure other relationships, is the statistically very clear correlation of isotopic value against time; there is a significant change in $\delta^{15} \mathrm{~N}$ values and a smaller change in $\delta^{13} \mathrm{C}$ values over time. The correlation $\left(\mathrm{R}^{2}=0.59\right)$ between $\delta^{15} \mathrm{~N}$ and the midpoint of the posterior density estimates represents an overall increase of $3 \%$ in $\delta^{15} \mathrm{~N}$. This is a significant shift in $\delta^{15} \mathrm{~N}$ enrichment - almost equivalent to what might be expected for a whole trophic level shift (Fig. 12). The changes in the $\delta^{13} \mathrm{C}$ values are less marked. The correlation $\left(\mathrm{R}^{2}=0.34\right)$ between $\delta^{13} \mathrm{C}$ and the mid-point of the posterior density estimates is equivalent to an overall increase of $1 \%$. There appear to be more outliers in this plot (Fig. 13). The correlations between the stable isotope changes have opposite slopes, though there is clearly proportional correlation between the $\delta^{15} \mathrm{~N}$ and $\delta^{13} \mathrm{C}$ values. Given these trends, it is difficult to envisage the 'driving mechanism' responsible, and the changes cannot definitely be ascribed to a common process. A similar trend in British Iron Age pig populations has been noted by one of us, though the reason for these changes is likely to be very different (Hamilton et al. 2009). The earlier use of the monument shows a temporal clustering distinct from the later use of the monument (Figs 12-14). The later data still retain some temporal structure in $\delta^{15} \mathrm{~N}$ (which is the main discriminating isotopic axis). These interpretations 


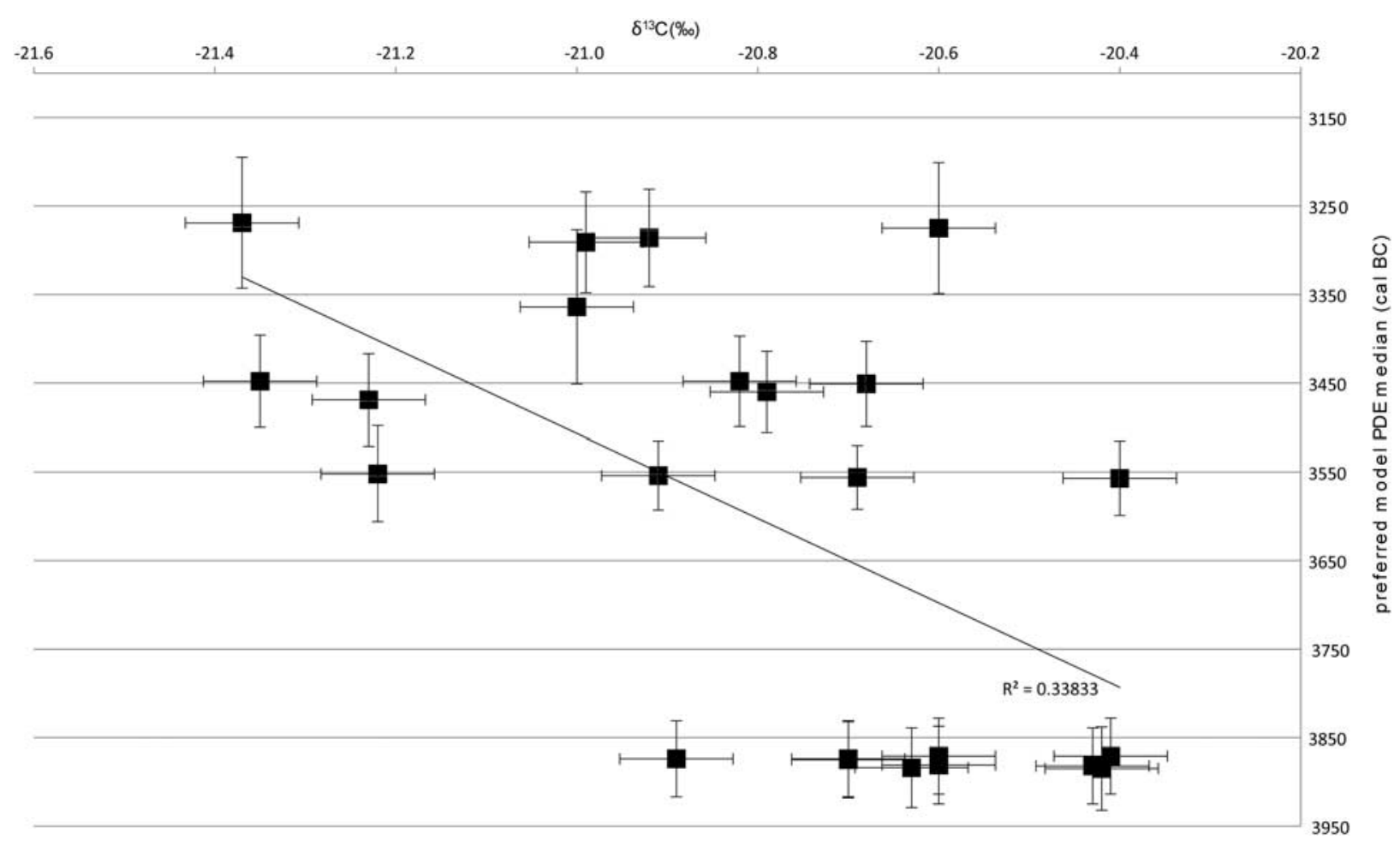

Fig. 13.

Changes in $\delta^{13} \mathrm{C}$ values over time. The horizontal axis plots $\delta^{15} \mathrm{C}$ (with estimated analytical error); the vertical axis plots the posterior density estimate median and standard deviation range from the preferred model (model 2, Fig. 8)

are somewhat speculative; certainly the data support a model of change in diet over time and this evidence may be relevant to understanding the cause.

\section{Discussion}

As so often with data limited to two isotopic values, several hypotheses can be constructed in explanation. We suggest several possibilities, which may not be mutually exclusive. First, the shift could be due to a change in the isotopic composition of the same basic diet, arising from change in the environment where the food is produced. Were the local food source $\delta^{15} \mathrm{~N}$ values to be enriched relative to the rest of the country there would be a proportional enrichment in the human population. This could arise from increased intensive use of animal manure (affecting both plants and animals; Bogaard et al. 2007; Hedges \& Reynard 2007; Fraser et al. 2011), or the exploitation of grazing land unusually enriched in $\delta^{15} \mathrm{~N}$.

The proximity of Coldrum to the Medway estuary allows us to consider the possibility of $\delta^{15} \mathrm{~N}$ enrichment in saline conditions (Britton et al. 2008; Schulting et al. 2010b) or perhaps also in estuarine anoxic (i.e. denitrifying) conditions (cf. Olsen et al. 2011; Ohte 2012). Change through time might result from gradual change in sedimentation patterns, or in the management of available grazing lands, or other changes in estuarine or river hydrology (Darling 2004). From the available data, in general environmental situations involving an increase in $\delta^{15} \mathrm{~N}$ tend to imply an increase in $\delta^{13} \mathrm{C}$ (e.g. Britton et al. 2008). In the case of Coldrum, the increase in $\delta^{15} \mathrm{~N}$ values is accompanied by a small decrease in $\delta^{13} \mathrm{C}$ values. The stable isotope patterning from Coldrum requires further investigation of possible values entering the human food chain in estuarine environments, and specifically in the Neolithic Medway (cf. Olsen et al. 2011; Ohte 2012).

A second possibility is a change in diet over time. Without local fauna, this is impossible to document clearly, and in any case, the issue is not simple (Hedges \& Reynard 2007). A shift from a modest exploitation of cow to a large emphasis on pig, for 


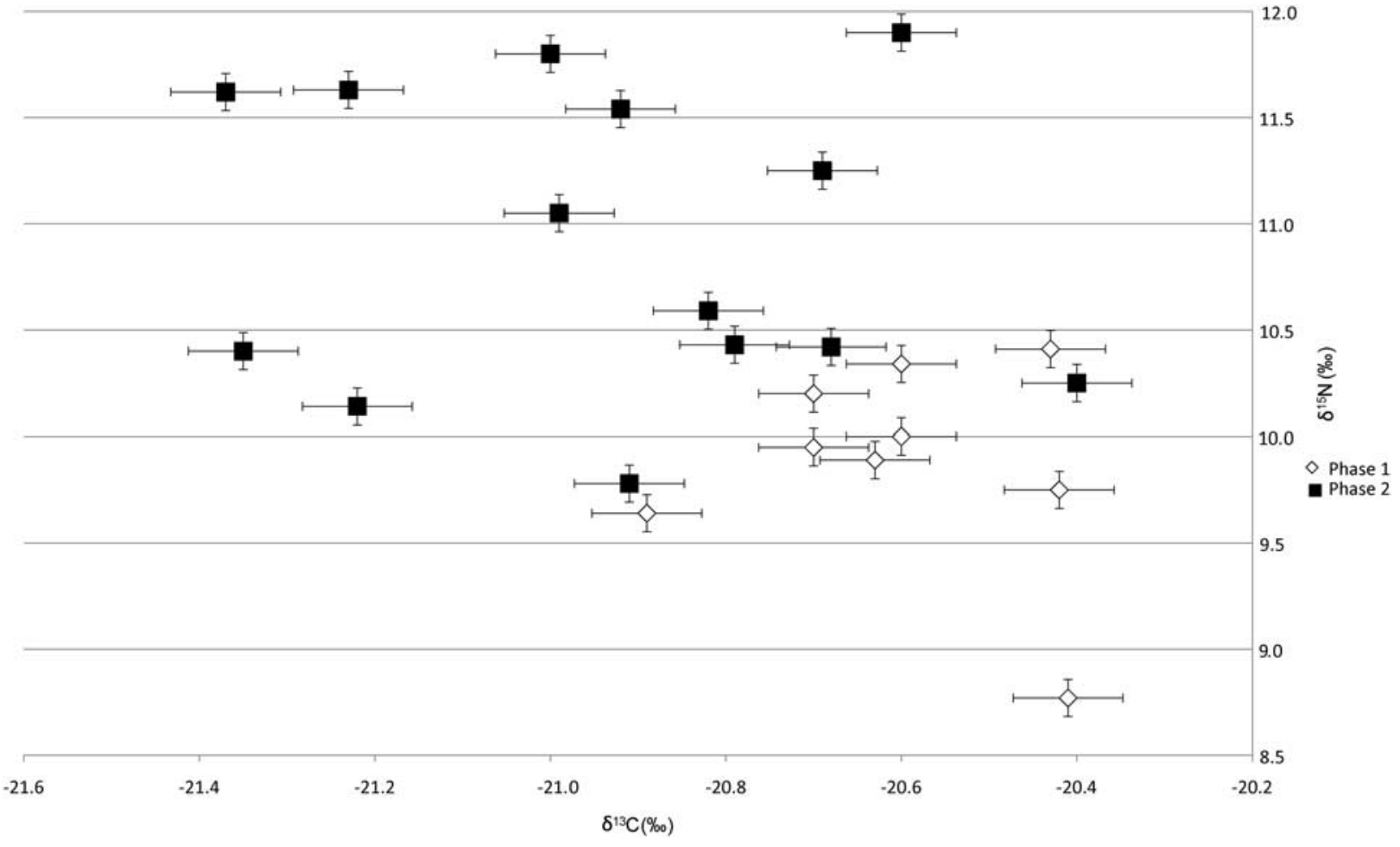

Fig. 14.

A plot of $\delta^{13} \mathrm{C}$ against $\delta^{15} \mathrm{~N}$ values (with estimated analytical error). We differentiate between samples which we suggest may represent an early phase of activity at the site (Phase 1) and samples that represent later activity at the site. Our interpretive phasing - based on radiocarbon statistical consistency and the association of two skulls with the lower platform (Bennett 1913) - appears to be supported by the trend in stable isotope data towards increasing enrichment in $\delta^{15} \mathrm{~N}$ values in the later phase of activity at the site

example, might explain a $2 \%$ shift in $\delta^{15} \mathrm{~N}$, but such a scenario would have to involve very large quantities of pig as a percentage of the diet, and in any case the $\delta^{15} \mathrm{~N}$ value (which is already high in early individuals) would require additional explanation. Other possibilities that could contribute to the $\delta^{15} \mathrm{~N}$ enrichment could include for example the consumption of pigs raised on milk.

As noted, fish consumption could also elevate $\delta^{15} \mathrm{~N}$ values. However, for Coldrum the decrease in $\delta^{13} \mathrm{C}$ as $\delta^{15} \mathrm{~N}$ increases is decisive evidence that marine resources were not consumed. It remains possible that freshwater or migratory fish (including eels, Anguilla anguilla) are responsible for the elevated $\delta^{15} \mathrm{~N}$ in later skeletons, and the later population may therefore have a reservoir offset (which we think is not significant in terms of the start of activity at the monument). Too little is known of freshwater reservoir effects for involved discussion of possible effects on radiocarbon measurements from the later individuals (in the literature, only examples of significant reservoir effects have been reported; e.g. Cook et al. 2001; 2002; cf. Keaveney and Reimer 2012). The $\delta^{13} \mathrm{C}$ values are consistent with either a freshwater fish dietary content, or a basically (though perhaps complex) terrestrial source. Importantly, the results argue against the $\delta^{15} \mathrm{~N}$ increase as a purely trophic level effect (where $\delta^{13} \mathrm{C}$ tends to increase along with $\delta^{15} \mathrm{~N}$, rather than decrease as seen here).

Current interpretations of stable isotope evidence for the early Neolithic (Richards 2003; Schulting \& Richards 2002) suggest that there is no other evidence for fish consumption in mainland Britain. Outside mainland Britain evidence for elevated $\delta^{15} \mathrm{~N}$ values from the three burials at Le Déhus has been observed by Schulting et al. (2010b) and a convincing explanation is similarly elusive. As Schulting et al. (2010b) discuss, a number of subsistence strategies could result 
in these data, including significant reliance on A. anguilla, or consumption of manured cereal crops, or exploitation of coastal marshes as animal pasture. At both Le Déhus and Coldrum it must be emphasised that the potential sources of the isotopic enrichment could include a combined environmental and dietary selection effect.

Finally, it is possible that the changes did not result from a 'directional' change in diet - an increasing emphasis on an aspect of a subsistence repertoire over time, but from diverse dietary repertoires, which may have changed over times. In this scenario the change in negative correlation of the $\delta^{13} \mathrm{C}$ and $\delta^{15} \mathrm{~N}$ values would not be related and the trends are coincidental. Even were the trend coincidental, the elevation in $\delta^{15} \mathrm{~N}$ values of the later individuals remains highly significant, unusual and currently without satisfactory explanation.

\section{SUMMARY AND DISCUSSION}

We have established that the remains of a minimum of 17 individuals - men, women, and children - were deposited in the western part of the chamber. One adult male suffered a blow to the head; an adult female skull exhibited trauma and cut-marks (Schulting \& Wysocki 2005). At least one adult, probably male, had cutmarked bones, which may have resulted from the separation of the upper thigh from the hip, perhaps to hasten the disarticulation process.

Isotopic analysis revealed $\delta^{13} \mathrm{C}$ values typical for many Neolithic sites in southern Britain, but significantly enriched values of $\delta^{15} \mathrm{~N}$, which were further enhanced through time. In the absence of local faunal data, these patterns are difficult to interpret but could reflect a terrestrial diet high in animal protein supplemented by some reliance, which may have increased through time, on freshwater river (or conceivably estuarine) resources. We cannot yet satisfactorily explain the pattern of stable isotopes, but these data emphasise the potential importance of complex dietary inputs, as well as the need for multi-isotope studies (e.g. sulphur and strontium: Bickle \& Whittle 2013; Nehlich et al. 2010). Of great benefit to the current study would be further research into the isotopic signals of resources from riverine and estuarine environments (cf. Keaveney \& Reimer 2012); the potential for complex carbon and nitrogen cycling in such regions requires reference points from, for example, terrestrial animals subsisting in salt marsh, and aquatic and semiaquatic plant and animal resources at various locations across estuary environments. Such data are essential to contextualise our understandings of cultivation and animal husbandry strategies, such as manuring (Bogaard et al. 2007; 2011).

Posterior density estimates from our preferred model suggest that the monument was first used in 3980-3800 cal BC (95\% probable) or 3960-3880 cal $B C(68 \%$ probable; start Coldrum 1 model 2; Fig. 8$)$. The later 'phase' we have employed for analysis purposes may in fact represent activity that was episodic and occurred over a considerable period of time. The interval between the first phase of activity which we have suggested and subsequent activity was probably greater than the lifespan of any individual, and may have been significantly longer $(60-350$ years; 95\% probable; or 140-290 years; 68\% probable; Coldrum 1/2; Fig. 9). Subsequent activity probably began in $3730-3540$ cal BC $(95 \%$ probable $)$ or $3670-3560$ cal BC $(68 \%$ probable; start Coldrum 2 model 2; Fig. 8).

Despite the density of Neolithic mortuary monuments in England and Wales relatively few have sufficient appropriate data to allow robust, explicit, and quantifiable estimates for their use or construction. Many such monuments do not seem to have been constructed before the 38th century cal BC (Bayliss \& Whittle 2007; Whittle et al. 2011b). A possible comparison for Coldrum may be identified at Burn Ground in the Cotswolds (Smith \& Brickley 2006; Dixon et al. 2011), which may have been constructed in 4140-3760 cal BC (95\% probable) or 3985-3875 cal BC (46\% probable) or 3860-3790 cal BC $(22 \%$ probable; start Burn Ground; Smith \& Brickley 2006, fig. 9.25; Dixon et al. 2011, 468). However, this monument also has a number of caveats in its chronological interpretation.

The morphology of the Medway monuments may be regarded as unusual in comparison with other early Neolithic mortuary sites (but see Ashbee 2005, 108). This has been suggested to be associated with continental influence or origins; the 'northern' (Ashbee 1998, 36) or 'Nordic' (Piggott in Jessup 1939, 267) polished flint axe from the Julliberrie's Grave monument might underline such associations. While the Julliberrie's Grave axe has been identified as a foreign example, the petrological provenance of the item remains uncertain and is the subject of further research (Katharine Walker, pers. comm. 2012; see also Darvill 2010, 126; Barrett et al. 1991, 54; Ashbee 2005, 98). 


\section{Prior start Coldrum 1 model 2}

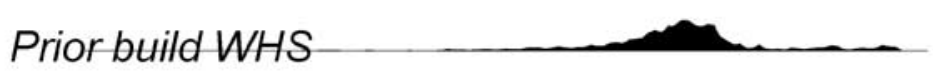

Prior Start Sussex flint mines

Prior KIA-21057

Prior End Sussex flint mines

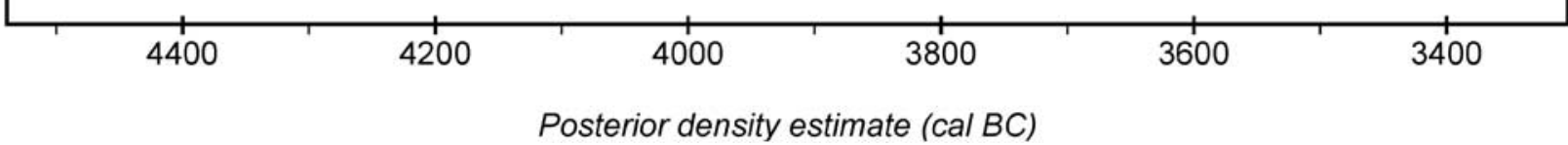

Fig. 15.

Comparison of the posterior density estimates from Coldrum, Yabsley Street, White Horse Stone, and the Sussex flint mines. The models for White Horse Stone, Yabsley Street, (KIA-21057), and the Sussex flint mines have been recalculated using OxCal v4.1, but follow the model structure shown in Bayliss et al. (2011a, 379, fig. 7.26), Bayliss et al. (2011b, 731, fig. 14.49), and Bayliss et al. (2011b, 793, fig. 14.129)

The distinctiveness of the Medway monuments could reflect local developments or experiments with styles and customs, which only later became more widespread in Britain after the 38th century cal BC (Whittle et al. 2007; 2011b; Griffiths 2011). Without further chronological evidence for the local Medway monuments, or better dating of possibly related monuments from the continent (cf. Whittle et al. 2011b), it is difficult to assess the role of Coldrum within early Neolithic monument traditions.

We can provide a more general context for the early Neolithic in the Thames Estuary and southern England. Some of us (Whittle et al. 2011b; Griffiths 2011) have presented data which strongly suggest that the Greater Thames Estuary was probably the region which witnessed the earliest Neolithic material culture and practices in England, Wales, Ireland, and parts of Scotland (note continuing uncertainty over the chronology of the Irish causewayed enclosure at Magheraboy, Co. Sligo: Cooney et al. 2011; cf. Sheridan 2010; 2012).

Other robustly dated examples of early Neolithic practices in the Thames Estuary include the Yabsley inhumation (in which bowl pottery was deposited) in 4230-3980 cal BC (95\% confidence; or 4060-3990 cal BC $(68 \%$ confidence; KIA-20157; $5252 \pm 28$ BP;
Coles et al. 2008); and the first activity at the postand-slot structure at White Horse Stone (Hayden \& Stafford 2006; Garwood 2011) in 4115-3825 cal BC (95\% probable) or $4065-3940$ cal BC $(68 \%$ probable; build WHS; Bayliss et al. 2011a, 379; fig. 7.26). In south-east England, other important early Neolithic activity included flint axe extraction in the Sussex flint mines in $4145-3805 \mathrm{cal} B C(95 \%$ probable $)$ or 4020-3855 cal BC $(68 \%$ probable; start Sussex flint mines; Bayliss et al. 2011b, 789, fig. 14.129).

The oldest remains deposited at Coldrum represent people who most probably died in the late 40th-early 39th centuries cal BC $(3960-3880$ cal BC; 68\% probable; start Coldrum 1 model 2; Fig. 8). While part of the regional early Neolithic, it is highly probable that the Coldrum monument was not the earliest expression of Neolithic activity in the southeast and Thames Estuary; it is $89 \%$ probable that the White Horse Stone structure was in use before activity at Coldrum. It is $100 \%$ probable that the Yabsley burial occurred before Coldrum. It is more probable (61\% probable) that the earliest activity at the Sussex flint mines occurred before the start of use of the Coldrum monument, though the start of activity at Coldrum occurred before the end of activity at the flint mines (Fig. 15), meaning that some of the people 
buried at Coldrum could have been contemporary with activity at the Sussex flint mines.

A number of early Neolithic causewayed enclosures are known from the region, at St Osyth, Essex (Germany 2007), Kingsborough 1 and 2, Isle of Sheppey (Allen \& Leivers 2008), and Chalk Hill, Ramsgate (Dyson et al. 2000). However, chronological modelling indicates that these sites were also not part of the earliest regional Neolithic (Healy et al. 2011). The initial construction of the causewayed enclosure at Burham on the east side of the Medway valley itself has recently been dated to the early 37 th century cal BC (Paul Garwood, pers. comm. 2012; Garwood 2012, 3).

There is limited evidence with which to understand relationships between populations with access to the earliest Neolithic and the latest Mesolithic material culture and lifeways in the Greater Thames Estuary. Mesolithic lithic scatters and find spots are located on greensand deposits at the foot of the North Downs, and elsewhere (Ashbee 2005, 79; Garwood 2011, fig. 3.9), but the continuing dearth if not absence of very late sites, despite the scale of recent investigations, remains striking (Garwood 2011, 52). Notable is the sizeable Mesolithic scatter on the greensand at Addington (Ashbee 2005, 80). Here the Chestnuts tomb directly overlay part of the flint scatter (Alexander 1959; 1962); Mesolithic activity at the site may have been associated with a possible posthole and hearth (Fisher 1939, 147; Jessup 1950, 55). Ashbee $(2005,80)$ suggests that the long barrows at Addington '.. were deliberately sited upon this Greensand area, because of its deep-rooted associations, and not on the chalk like their fellows'; this should, however, be contrasted with the concentrations of early Neolithic monuments on Greensand outside Wessex, for example in the distribution of monuments in Lincolnshire (Griffiths 2011, 87). In addition, the limited evidence for latest Mesolithic activity in the region means that we should be wary about associating superimposition or shared location as evidence for continuity between people engaged with latest Mesolithic lifeways and those with access to the earliest Neolithic traditions (Griffiths 2011).

One possible 'transition' site in Kent is the lithic assemblage from Erith. Here the very large late Mesolithic assemblage and diagnostic early Neolithic assemblage (which includes pottery) might suggest that activity continued across 'the transition' without discernible changes in lithic raw material procurement, technology, or depositional practice, though this site is not without problems of interpretation (Leivers unpublished seminar presentation; pers. comm. 2012). Chronometric data from Kent - at Charlwood, High Rocks, and Finglesham - which have been argued to suggest evidence for 'transitional' Mesolithic-Neolithic activity are also problematic (as discussed by Healy at a recent South-East Research Framework Resource Assessment Seminar).

The importance of river valleys in the early Neolithic and later has been emphasised in other regions, for example in the Nene valley (Healy et al. 2007), the Trent (e.g. Loveday 2000; Brightman 2009; Beamish 2009), and Wessex (Leary \& Field 2012). The siting of the Medway monuments (Fig. 1) might provide further evidence of that significance (cf. Loveday 2006). The Medway monument locations raise the potential of the river network as a major routeway - perhaps including as a means by which Neolithic material culture was brought to Britain (cf. Garrow \& Sturt 2011). Ongoing strontium and oxygen isotope analysis to investigate the origins and mobility of the Coldrum population will contribute to this debate (Samantha Neil and Chris Scarre, pers. comm.); aDNA analysis would also be highly desirable.

Ink continues to be poured on the Big Question of the Mesolithic-Neolithic transition, with protagonists for both colonisation (e.g. Sheridan 2000; 2003; 2004; 2007; 2010; Sheridan \& Pailler 2011; Schulting 2000; Schulting et al. 2010b) and indigenous change (e.g. Thomas 1999; 2003; 2007; 2008; 2013) until recently still to the fore; both approaches have used informal inspection of the radiocarbon evidence. Fusion or integrationist models have also now been proposed (Whittle 2007; Whittle et al. 2011a; cf. Zvelebil \& Lukes 2008), and some of us (Whittle et al. 2011a) have also recently discussed elsewhere, in a Bayesian framework providing explicit, quantified, and probabilistic date estimates, the context of and processes by which early Neolithic material culture and practices first appeared in Britain. From those perspectives, the first Neolithic things and practices probably appeared in the area of the Greater Thames Estuary, in the 41st century cal BC, shortly followed by Sussex; the model proposed was of small-scale movement of population from the adjacent continent, an offshoot of extensive changes in the world of the Michelsberg and perhaps northern Chasséen cultures, with subsequent and accelerating movement to the west and north of Britain, combined with acculturation 
of the indigenous population (Whittle et al. 2011a). The general comparisons made in the literature with continental monuments suggest no specific European antecedents for the form of monument at Coldrum, though by its probable start date megalithic construction had begun in north-west France (Cassen et al. 2009), and more modest monuments are known in the Aisne valley (Demoule 2007). The idea of building monuments of this kind therefore seems certainly to have pre-dated Coldrum, but whether such construction in Kent was effected by early generations of immigrants, or their descendants, or by a slightly later and more mixed population, remains an open question for continuing research.

Acknowledgments: Osteological analysis by Michael Wysocki was undertaken as part of a larger research project, directed by Alasdair Whittle and made possible by an Institutional Award from the Leverhulme Trust. A first round of radiocarbon measurements was funded by NERC; the results of these measurements were recognised to have been subject to a processing issue at the laboratory (Bronk Ramsey et al. 2004a; Brock et al. 2007), were withdrawn and are not reported here. A second round of radiocarbon dates and stable isotope analysis were produced by ORAU to investigate this issue; further research was undertaken as an AHRB-funded MSc project by Seren Griffiths. Initial modelling generated as part of this MSc thesis was presented in Whittle et al. (2011b), as part of the dating project on causewayed enclosures, joint-funded by English Heritage and AHRC.

We thank Louise Humphrey, Robert Kruszinsky, and Jerry Hooker of the Vertebrates and Anthropology Section, Palaeontology Department, Natural History Museum, London, and Maggie Bellatti and Martha Lehr of the Duckworth Laboratory Collection for access to their human remains collections and for permission to take samples. Giles Guthrie, Keeper of Human History at Maidstone Museum and Bentlif Art Gallery, provided access to and information on the Coldrum archive. We are grateful to Tamsin O'Connell for comments and support. Peter Andrews, then of the Palaeontology Department Natural History Museum, London, confirmed the initial cut-mark identification, and offered comments and observations. Kirsty Harding and Derek Hamilton helped prepare figures. Megan Brickley and Paul Garwood read and commented on earlier versions of this paper, and we also are grateful to three anonymous referees for their constructive criticism.

\section{BIBLIOGRAPHY}

Alexander, J. 1959. Addington: the Chestnuts megalithic tomb. Archaeologia Cantiana 72, 191-2

Alexander, J. 1962. The excavation of the Chestnuts megalithic tomb at Addington, Kent. Archaeologia Cantiana 76, 1-57
Allen, M. \& Leivers, M. 2008. Neolithic causewayed enclosures and later prehistoric farming: duality, imposition and the role of predecessors at Kingsborough, Isle of Sheppey, Kent, UK. Proceedings of the Prehistoric Society 74, 235-322

Ashbee, P. 1993. The Medway megaliths in perspective. Archaeologia Cantiana 111, 57-111

Ashbee, P. 1998. Coldrum revisited and revised. Archaeologia Cantiana 78, 1-44

Ashbee, P. 2000. The Medway's megalithic long barrows. Archaeologia Cantiana 120, 319-45

Ashbee, P. 2005. Kent in Prehistoric Times. Stroud: Tempus

Barber, M. 2004. 'Rubbishy pots instead of gold': a brief history of the Neolithic of the south-east. In Cotton \& Field (eds) 2004, 1-11

Barrett, J., Bradley, R. \& Green, M. 1991. Landscape, Monuments and Society: the prehistory of Cranborne Chase. Cambridge: Cambridge University Press

Bass, W. 1992. Human Osteology: a laboratory and field manual (3rd edn). Columbia: Missouri Archaeological Society

Bayliss, A. \& Whittle, A. (eds) 2007. Histories of the Dead: building chronologies for five southern British long barrows. Cambridge Archaeological Journal 17.1 (supplement)

Bayliss, A., Bronk Ramsey, C., Plicht, J. van der \& Whittle, A. 2007a. Bradshaw and Bayes: towards a timetable for the Neolithic. In Bayliss \& Whittle (eds) 2007, 1-28

Bayliss, A., Whittle, A. \& Wysocki, M. 2007b. Talking about my generation: the date of the West Kennet long barrow. In Bayliss \& Whittle (eds) 2007, 85-101

Bayliss, A., Allen, M., Healy, F., Whittle, A., Germany, M., Griffiths, S., Hamilton, D., Higham, T., Meadows, J., Shand, G., Stevens, S. \& Wysocki, M. 2011a. The Greater Thames estuary. In Whittle et al. 2011b, 348-86

Bayliss, A., Healy, F., Whittle, A. \& Cooney, G. 2011 b. Neolithic narratives: British and Irish enclosures in their timescapes. In Whittle et al. 2011b, 682-847

Beamish, M. 2009. Island visits: Neolithic and Bronze Age activity on the Trent valley floor: excavations at Egginton and Willington, Derbyshire, 1998-1999. Derby Archaeological Journal 129, 17-172

Bennett, F. 1913. Coldrum monument and exploration 1910. Journal of the Royal Anthropological Institute 43, 76-85

Bewley, B., Crutchley, S. \& Grady, D. 2004. Aerial survey and its contribution to understanding the Neolithic of the south-east. In Cotton \& Field (eds) 2004, 71-5

Bickle, P. \& Whittle, A. (eds) 2013. The First Farmers of Central Europe: diversity in LBK lifeways. Oxford: Oxbow Books

Bogaard, A., Heaton, T., Poulton, P. \& Merbach, I. 2007. The impact of manuring on nitrogen isotope ratios in cereals: archaeological implications for reconstruction of diet and crop management practices. Journal of Archaeological Science 34, 335-43

Bogaard, A., Krause, R. \& Strien, H.-C. 2011. Towards a social geography of cultivation and plant use in an early 


\section{Wysocki et al. DATES, DIET, \& DISMEMBERMENT: COLDRUM MEGALITHIC MONUMENT, KENT}

farming community: Vaihingen an der Enz, south-west Germany. Antiquity 85, 395-416

Booth, P., Champion, T., Garwood, P., Glass, H., Munby, J. \& Reynolds, A. 2011. On Track: the archaeology of High Speed 1 Section 1 in Kent. Oxford: Oxford Archaeology

Boulestin, B., Zeeb-Lanz, A., Jeunesse, C., Haack, F., Arbogast, R.-M. \& Denaire, A. 2009. Mass cannibalism in the Linear Pottery Culture at Herxheim (Palatinate, Germany). Antiquity 83, 968-82

Box, G. 1979. Robustness in scientific model building. In R. Launer \& G. Wilkinson (eds), Robustness in Statistics, 201-36. New York: Academic Press

Brightman, J. 2009. Mercia Marina, Findern Lane, Willington, Derbyshire: report on an archaeological excavation. Bakewell: ARS Ltd, unplublished report

Britton, K., Müldner, G. \& Bell, M. 2008. Stable isotope evidence for salt-marsh grazing in the Bronze Age Severn Estuary, UK: implications for palaeodietary analysis at coastal sites. Journal of Archaeological Science 35, 2111-18

Brock, F., Bronk Ramsey, C. \& Higham, T. 2007. Quality assurance of ultrafiltered bone dating. Radiocarbon 49, 187-92

Brock, F., Higham, T., Ditchfield, P. \& Bronk Ramsey, C. 2010. Current pretreatment methods for AMS radiocarbon dating at the Oxford Radiocarbon Accelerator Unit (ORAU). Radiocarbon 52, 103-12

Bronk Ramsey, C. 1995. Radiocarbon calibration and analysis of stratigraphy: the OxCal program. Radiocarbon 37, 425-30

Bronk Ramsey, C. 1998. Probability and dating. Radiocarbon 40, 461-74

Bronk Ramsey, C. 2001. Development of the radiocarbon calibration program OxCal. Radiocarbon 43, 355-63

Bronk Ramsey, C. 2009. Bayesian analysis of radiocarbon dates. Radiocarbon 51, 337-60

Bronk Ramsey, C., Higham, T., Bowles, A. \& Hedges, R. 2004a. Improvements to the pre-treatment of bone at Oxford. Radiocarbon 46, 155-63

Bronk Ramsey, C., Higham, T. \& Leach, P. 2004b. Towards high precision AMS: progress and limitations. Radiocarbon 46, 17-24

Buck, C., Kenworthy, J., Litton, C. \& Smith, A. 1991. Combining archaeological and radiocarbon information: a Bayesian approach to calibration. Antiquity 65, 808-21

Buck, C., Litton, C. \& Smith, A. 1992. Calibration of radiocarbon results pertaining to related archaeological events. Journal of Archaeological Science 19, 487-512

Buck, C., Cavanagh, W. \& Litton, C. 1996. Bayesian Approach to Interpreting Archaeological Data. Chichester: Wiley

Buikstra, J. \& Ubelaker, D. 1994. Standards for Data Collection from Human Skeletal Remains. Fayetteville, Arkansas: Arkansas Archaeological Survey

Cassen, S. (ed.) 2009. Autour de la Table: explorations archéologiques et discourse savants sur des architectures mégalithiques à Locmariaquer, Morbihan (Tables des Marchands et Grand Menhir). Nantes: Laboratoire de recherches archéologiques, CNRS and Université de Nantes
Cassen, S., Lanos, P., Dufresne, P., Oberlin, C., DelquéKolic, E. \& Le Goffic, M. 2009. Datations sur site (Table des Marchands, alignement du Grand Menhir, Er Gah) et modélisation chronologiqie du Néolithisation morbihannais. Autour de la Table: explorations archaéologiques et discours savants sur des architectures néolithiques á Locmariaquer. In S. Cassen, Nantes; Laboratoire de recherches archéologiques, 737-68. Paris: CNRS and Université de Nantes

Clarke, A. 1982. The Neolithic of Kent: a review. In P. Leach (ed.), Archaeology in Kent to AD 1500. London: Council for British Archaeology Research Report 48

Coles, S., Ford, S. \& Taylor, A. 2008. An early Neolithic grave and occupation, and an early Bronze Age hearth on the Thames foreshore at Yabsley Street, Blackwall, London. Proceedings of the Prehistoric Society 74, 215-34

Cook, G., Bonsall, C., Hedges, R., McSweeney, K., Boroneant, V. \& Pettitt, P. 2001. A freshwater dietderived ${ }^{14} \mathrm{C}$ reservoir effect at the Stone Age sites in the Iron Gates gorge. Radiocarbon 43, 453-60

Cook, G., Bonsall, C., Hedges, R., McSweeney, K., Boroneanţ, A., Bartosiewicz, L. \& Pettitt, P. 2002. Problems of dating human bones from the Iron Gates. Antiquity 76, 77-85

Cooney, G., Bayliss, A., Healy, F., Whittle, A., Danaher, E., Cagney, L., Mallory, J., Smyth, J., Kador, T. \& O'Sullivan, M. 2011. Ireland. In Whittle et al. 2011b, 562-669

Cotton, J. \& Field, D. (eds) 2004. Towards a New Stone Age: aspects of the Neolithic in south-east England. York: Council for British Archaeology Research Report 137

Daniel, G. 1950. The Prehistoric Chamber Tombs of England and Wales. Cambridge: Cambridge University Press

Darling, W.G. 2004. Hydrological factors in the interpretation of stable isotopic proxy data present and past; a European perspective. Quaternary Science Review 23, 743-70

Darvill, T. 2010. Prehistoric Britain. London: Routledge

Dee, M. \& Bronk Ramsey, C. 2000. Refinement of the graphite target production at ORAU. Nuclear Instruments and Methods in Physics Research B 172, 449-53

Demoule, J.-P. 2007. L'origine des inegalités. In J.-P. Demoule, R. Cottiaux, J. Dubouloz, F. Giligny, L. Jallot, L. Monolakakis, G. Marchand \& I. Sénépart, La révolution néolithique en France, 78-95. Paris: La Découverte

Dixon, P., Bayliss, A., Healy, F., Whittle, A. \& Darvill, T. 2011. The Cotswolds. In Whittle et al. 2011b, 434-520

Dyson, L., Shand, G. \& Stevens, S. 2000. Causewayed enclosures. Current Archaeology 4.12, 470-2

Eickhoff, S. \& Herrmann, B. 1985. Surface marks on bones from a Neolithic collective grave (Odagsen, Lower Saxony): a study on differential diagnosis. Journal of Human Evolution 14, 263-74

Evans, J. 1949. A disciple of the druids. The Beale Poste MSS. Archaeologia Cantiana 72, 130-9

Evans, J. 1950. Kentish megalithic types. Archaeologia Cantiana 63, 63-81 
Filkins, E. 1928. Excavations at Coldrum, Kent. Antiquaries Journal 8, 356-7

Fisher, C. 1939. Archaeology in Kent 1938. Archaeologia Cantiana 50, 147

Fraser, R., Bogaard, A., Heaton, T., Charles, M., Jones, G., Christensen, B., Halstead, P., Merbach, I., Poulton, P., Sparkes, D. \& Styring, A. 2011. Manuring and stable nitrogen isotope ratios in cereals and pulses: towards a new archaeobotanical approach to the inference of land use and dietary practices. Journal of Archaeological Science 38, 2790-804

Garrow, D. \& Sturt, F. 2011. Grey waters bright with Neolithic argonauts? Maritime connections and the MesolithicNeolithic transition within the 'western seaways' of Britain, c. 5000-3500 вС. Antiquity 85, 59-72

Garwood, P. 2011. Early prehistory. In Booth et al. 2011, $37-150$

Garwood, P. 2012. The Medway Valley Prehistoric Landscapes Project. PAST 72, 1-3

Germany, M. 2007. Neolithic and Bronze Age Monuments and Middle Iron Age Settlement at Lodge Farm, St Osyth, Essex: excavations 2000-3. Chelmsford: East Anglian Archaeology 117

Glass, H. 2000. White Horse Stone - a Neolithic longhouse. Current Archaeology 14, 450-3

Griffiths, S. 2011. Chronological Modelling of the Mesolithic-Neolithic Transition in the North and Midlands of England and Wales. Unpublished $\mathrm{PhD}$ thesis, Cardiff University

Haglund, W.D. 1997. Dogs and coyotes: postmortem involvement with human remains. In W.D. Haglund \& M.H. Sorg (eds), Forensic Taphonomy: the postmortem fate of human remains, 367-81. Boca Raton: CRC Press

Hamilton, J., Hedges, R. \& Robinson, M. 2009. Rooting for pigfruit: pig feeding in Neolithic and Iron Age Britain compared. Antiquity 83, 998-1011

Hayden, C. \& Stafford, E. 2006. The prehistoric landscape at White Horse Stone, Aylesford, Kent: CTRL integrated site report series. Unpublished report: http://archaeology dataservice.ac.uk/archives/view/ctrl/whsisr/downloads.cfm? volume $=$ documentation $\&$ CFID $=45833 \&$ CFTOKEN $=$ 797DC47F-E891-4B25-BBCB7BDD0900A64A

Healy, F., Harding, J. \& Bayliss, A. 2007. The development of the monuments. In J. Harding \& F. Healy, The Raunds Area Project: a Neolithic and Bronze Age landscape in Northamptonshire, 37-198. Swindon: English Heritage

Healy, F., Bayliss, A. \& Whittle, A. 2011. Sussex. In Whittle et al. 2011b, 207-62. Oxford: Oxbow Books

Hedges, R., Bentley, A., Bickle, P., Cullen, P., Dale, C., Fibiger, L., Hamilton, J., Hofmann, D., Nowell, G. \& Whittle, A. 2013. The supra-regional perspective. In Bickle \& Whittle (eds) 2013, 343-86

Hedges, R. \& Reynard, L. 2007. Nitrogen isotopes and the trophic level of humans in archaeology. Journal of Archaeological Science 34, 1240-51

Hillson, S. 1996. Dental Anthropology. Cambridge: Cambridge University Press

Holgate, R. 1981. The Medway megaliths and Neolithic Kent. Archaeologia Cantiana 97, 221-34
Jessup, R. 1939. Further excavations at Julliberrie's Grave, Chilham. Antiquaries Journal 19, 260-81

Jessup, R. 1970. South-east England. London: Thames \& Hudson

Keaveney, E. \& Reimer, P. 2012. Understanding the variability in freshwater radiocarbon reservoir offsets: a cautionary tale. Journal of Archaeological Science 39, 1306-16

Keiller, A. \& Piggott, S. 1938. Excavation of an untouched chamber in the Lanhill long barrow. Proceedings of the Prehistoric Society 4, 122-50

Keith, A. 1913. Report on the human remains found by F.J. Bennett, Esq., F.G.S., in the central chamber of a megalithic monument at Coldrum, Kent. Journal of the Royal Anthropological Institute 43, 86-100

Keith, A. 1916. The human remains (St. Nicholas chambered tumulus). Archaeologia Cambrensis (6th ser.) 16, 268-93

Kelley, M. 1979. Sex determination with fragmented skeletal remains. Journal of Forensic Sciences 24, 154-158

Kinnes, I. 1992. Non-megalithic Long Barrows and Allied Structures in the British Neolithic. London: British Museum

Kinnes, I. 2004. Trans-Manche: l'entente cordiale or vive la différence. In Cotton \& Field (eds) 2004, 191-5

Leary, J. \& Field, D. 2012. Journeys and juxtapositions. Marden henge and the view from the Vale. In A. Gibson (ed.), Enclosing the Neolithic: recent studies in Britain and Europe, 55-65. Oxford: Archaeopress

Lee, F. \& Wakely, R. 2006. Human skeletal remains. In C. Evans \& I. Hodder, A Woodland Archaeology: Neolithic sites at Haddenham, 140-53. Cambridge: McDonald Institute for Archaeological Research

Loveday, R. 2000. Aston: a barrow preserved. Current Archaeology 167, 438-9

Loveday, R. 2006. Inscribed Across the Landscape: the cursus enigma. Stroud: Tempus

Lyman, R. 1994. Vertebrate Taphonomy. Cambridge: Cambridge University Press

Mays, S. 2004. A note on Neolithic human remains from south-east England. In Cotton \& Field (eds) 2004, 110-14

McKinley, J. 2008. Human remains. In R. Mercer \& F. Healy, Hambledon Hill, Dorset: excavation and survey of a Neolithic monument complex and its surrounding landscape, 477-521. Swindon: English Heritage

Megyesi, M.S., Nawrocki, S.P. \& Haskell, N.H. 2005. Using accumalated degree-days to estimate the postmortem interval from decomposed human remains. Journal of Forensic Sciences 50, 618-26

Nehlich, O., Borić, D., Stefanović, S. \& Richards, M. 2010. Sulphur isotope evidence for freshwater fish consumption: a case study from the Danube Gorges, SE Europe. Journal of Archaeological Science 37, 1131-9

Ohte, N. 2012. Tracing sources and pathways of dissolved nitrate in forest and river ecosystems using highresolution isotopic techniques: a review. Ecological Research, 1-9 (DOI 10.1007/s11284-012-0939-3) 


\section{Wysocki et al. DATES, DIET, \& DISMEMBERMENT: COLDRUM MEGALITHIC MONUMENT, KENT}

Olsen, S. \& Shipman, P. 1988. Surface modification on bone: trampling versus butchery. Journal of Archaeological Science 15, 535-53

Olsen, Y., Dausse, A., Garbutt, A., Ford, H., Thomas, D. \& Jones, D. 2011. Cattle grazing drives nitrogen and carbon cycling in a temperate salt marsh. Soil Biology and Biochemistry 43, 531-41

Piggott, S. 1931. The Neolithic pottery of the British Isles. Archaeological Journal 88, 67-158

Piggott, S. 1935. A note on the relative chronology of the English long barrows. Proceedings of the Prehistoric Society 1, 122

Piggott, S. 1962. The West Kennet Long Barrow: excavations 1955-56. London: Her Majesty's Stationery Office

Privat, K., O’Connell, T. \& Richards, M. 2002. Stable isotope analysis of human and faunal remains from the Anglo-Saxon cemetery at Berinsfield, Oxfordshire: dietary and social implications. Journal of Archaeological Science 29, 779-90

Reimer, P., Baillie, M., Bard, E., Bayliss, A., Beck, J., Blackwell, P., Bronk Ramsey, C., Buck, C., Burr, G., Edwards, R., Friedrich, M., Grootes, P., Guilderson, T., Hajdas, I., Heaton, T., Hogg, A., Hughen, K., Kaiser, K., Kromer, B., McCormac, F., Manning, S., Reimer, R., Richards, D., Southon, J., Talamo, S., Turney, C., Plicht, J. van der \& Weyhenmeyer, C. 2009. INTCAL09 and MARINE09 radiocarbon age calibration curves, 0-50,000 years Cal BP. Radiocarbon 51, 1111-50

Richards, M. 2003. Explaining the dietary isotope evidence for the rapid adoption of the Neolithic in Britain. In M. Parker Pearson (ed.), Food, Culture and Identity in the Neolithic and Early Bronze Age, 31-6. Oxford: British Archaeological Report S1117

Rolleston, G. 1876. On the people of the long barrow period. Journal of the Anthropological Institute 5, 120-73

Saville, A. 1990. Hazleton North: the excavation of a Neolithic long cairn of the Cotswold-Severn group. London: English Heritage

Savory, H. 1956. The excavation of the Pipton long cairn, Brecknockshire. Archaeologia Cambrensis 105, 7-48

Savory, H. 1984. The Penywyrlod long cairn, Talgarth, Brecknock. In W. Britnell \& H. Savory, Gwernvale and Penywyrlod: two Neolithic long cairns in Brecknock, 13-39. Cardiff: Cambrian Archaeological Association

Scheuer, L. \& Black, S. 2000. Developmental Juvenile Osteology. London: Academic Press

Schoeninger, M., Deniro, M. \& Tauber, H. 1983. Stable nitrogen isotope ratios of bone collagen reflect marine and terrestrial components of prehistoric diets. Science $216,1381-83$

Schulting, R. 2000. New AMS dates from the Lambourn long barrow and the question of the earliest Neolithic in southern England: repacking the Neolithic package? Oxford Journal of Archaeology 19, 25-35

Schulting, R. \& Richards, M. 2002. The wet, the wild and the domesticated: the Mesolithic-Neolithic transition on the west coast of Scotland. European Journal of Archaeology 5, 147-89
Schulting, R. \& Richards, M. submitted. Dietary shifts at the Mesolithic-Neolithic transition in Europe: an overview and meta-analysis. In J. Lee-Thorp \& M. Katzenberg (eds), Oxford Handbook of the Archaeology of Diet. Oxford: Oxford University Press

Schulting, R. \& Wysocki, M. 2005. 'In this chambered tumulus were found cleft skulls ...': an assessment of the evidence for cranial trauma in the British Neolithic. Proceedings of the Prehistoric Society 71, 107-138

Schulting, R., Sheridan, A., Crozier, A. \& Murphy, E. 2010a. Revisiting Quanterness: new AMS dates and stable isotope data from an Orcadian chamber tomb. Proceedings of the Society of Antiquaries 140, 1-50

Schulting, R., Sebire, H. \& Robb, J. 2010b. On the road to Paradis: new insights from AMS dates and stable isotopes at Le Déhus, Guernsey, and the Channel Islands middle Neolithic. Oxford Journal of Archaeology 29, 149-73

Sheridan, A. 2000. Achnacreebeag and its French connections: vive the 'auld alliance'. In J. Henderson (ed.), The Prehistory and Early History of Atlantic Europe, 1-16. Oxford: British Archaeological Report S861

Sheridan, A. 2003. French connections I: spreading the marmites thinly. In I. Armit, E. Murphy, E. Nelis \& D. Simpson (eds), Neolithic Settlement in Ireland and Western Britain, 3-17. Oxford: Oxbow Books

Sheridan, A. 2004. Neolithic connections along and across the Irish Sea. In V. Cummings \& C. Fowler (eds), The Neolithic of the Irish Sea: materiality and traditions of practice, 9-21. Oxford: Oxbow Books

Sheridan, A. 2007. From Picardie to Pickering and Pencraig Hill? New information on the 'Carinated Bowl Neolithic' in northern Britain. In Whittle \& Cummings (eds) 2007, 441-92

Sheridan, A. 2010. The Neolithization of Britain and Ireland: the 'Big Picture'. In B. Finlayson \& G. Warren (eds), Landscapes in Transition, 89-105. Oxford: Oxbow Books Sheridan, A. 2012. Review of A. Whittle, F. Healy \& A. Bayliss, Gathering Time: dating the early Neolithic enclosures of southern Britain and Ireland. Antiquity 86, 262-4

Sheridan, A. \& Pailler Y. 2011. La Néolithisation de la Grande-Bretagne et de l'Irlande: plusieurs processus, plusieurs modèles et des questions à l'attention de nos collègues français. In F. Bostyn, E. Martial \& I. Praud (eds), Le Néolithique du nord de la France dans son contexte européen: habitat et économie aux $4 e$ et $3 e$ millénaires avant notre ère, 13-30. Revue Archéologique de Picardie no. spécial 28

Sheridan, A., Schulting, R.J., Quinnell, H. \& Taylor, R. 2008. Revisiting a small passage tomb at Broadsands, Devon. Proceedings of the Devon Archaeological Exploration Society 66, 1-26

Shipman, P. \& Rose, J. 1983. Evidence of butchery activities at Torralba and Ambrona: an evaluation using microscopic techniques. Journal of Archaeological Science 10, 465-74

Smith, M. \& Brickley, M. 2004. Analysis and interpretation of flint toolmarks found on bones from West Tump long barrow, Gloucestershire. International Journal of Osteoarchaeology 14, 18-33 
Smith, M. \& Brickley, M. 2006. The date and sequence of use of Neolithic funerary monuments: new AMS dating evidence from the Cotswold-Severn region. Oxford Journal of Archaeology 25, 335-56

Smith, M. \& Brickley, M. 2009. People of the Long Barrows: life, death and burial in the earlier Neolithic. Stroud: History Press

Steele, D. \& Bramblett, C. 1988. The Anatomy and Biology of the Human Skeleton. College Station: Texas A \& M University Press

Steier, P. \& Rom, W. 2000. The use of Bayesian statistics for ${ }^{14} \mathrm{C}$ dates of chronological ordered samples: a critical analysis. Radiocarbon 42, 183-98

Stuiver, M. \& Polach, H. 1977. Discussion: reporting of ${ }^{14} \mathrm{C}$ data. Radiocarbon 19, 355-63

Stuiver, M. \& Reimer, P. 1986. A computer program for radiocarbon age calculation. Radiocarbon 28, 1022-30

Stuiver, M. \& Reimer, P. 1993. Extended ${ }^{14} \mathrm{C}$ data base and revised CALIB $3.0{ }^{14} \mathrm{C}$ age calibration program. Radiocarbon 35, 215-30

Thomas, J. 1999. Understanding the Neolithic. London: Routledge

Thomas, J. 2003. Thoughts on the 'repacked' Neolithic revolution. Antiquity 77, 67-74

Thomas, J. 2007. Mesolithic-Neolithic transitions in Britain: from essence to inhabitation. In Whittle and Cummings (eds) 2007, 423-39

Thomas, J. 2008. The Mesolithic-Neolithic transition in Britain. In J. Pollard (ed.), Prehistoric Britain, 58-89. Oxford: Blackwell

Thomas, J. 2013. The Birth of Neolithic Britain. Oxford: Oxford University Press

Toussaint, M. (ed.) 2003. Le champ mégalithique de Wéris. Fouilles de 1979 à 2001. Volume 1. Contexte archéologique et géologique. Namur: Division du Patrimoine

Toussaint, M., Frébutte, C. \& Hubert, F. (eds) 2009. Le champ mégalithique de Wéris. Fouilles de 1979 à 2001. Volume 2. Rapports des fouilles. Namur: Service publique de Wallonie et Institut du Patrimoine wallon

Turner, C. \& Turner, J. 1999. Man Corn: cannibalism and violence in the prehistoric American southwest. Salt Lake City: The University of Utah Press

Villa, P. \& Mahieu, E. 1991. Breakage patterns of human long bones. Journal of Human Evolution 21, 27-48
Villa, P., Bouville, C., Courtin, J., Helmer, D., Mahieu, E., Shipman, P., Belluomini, G. \& Branca, M. 1986. Cannibalism in the Neolithic. Science 233, 431-7

Ward, G. \& Wilson, S. 1978. Procedures for comparing and combining radiocarbon age determinations: a critique. Archaeometry 20, 19-31

White, T. 1992. Prehistoric Cannibalism at Mancos 5 MTUMR-2346. Princetown: Princetown University Press

White, T. 2000. Human Osteology (2nd edn). London: Academic Press

Whittle, A. 2007. The temporality of transformation: dating the early development of the southern British Neolithic. In Whittle \& Cummings (eds) 2007, 377-98

Whittle, A. \& Cummings, V. (eds) 2007. Going over: the Mesolithic-Neolithic transition in north-west. Oxford: Oxford University Press for The British Academy

Whittle, A. \& Wysocki, M. 1998. Parc le Breos Cwm transepted long cairn, Gower, West Glamorgan: date, contents and context. Proceedings of the Prebistoric Society 64, 139-82

Whittle, A., Bayliss, A. \& Healy, F. 2011a. Gathering time: the social dynamics of change. In Whittle et al. 2011b, 848-914

Whittle, A., Healy, F. \& Bayliss, A. 2011b. Gathering Time: dating the early Neolithic enclosures of southern Britain and Ireland. Oxford: Oxbow Books

Whittle, A., Barclay, A., Bayliss, A., McFadyen, L., Schulting, R. \& Wysocki M. 2007. Building for the dead: events, processes and changing worldviews from the thirty-eighth to the thirty-fourth centuries cal BC in southern Britain. In Bayliss \& Whittle (eds) 2007, 127-47

Wysocki, M. \& Whittle, A. 2000. Diversity, lifestyles and rites: new biological and archaeological evidence from British Earlier Neolithic mortuary assemblages. Antiquity 74, 591-601

Wysocki, M., Bayliss, A. \& Whittle, A. 2007. Serious mortality: the date of the Fussell's Lodge long barrow. In Bayliss \& Whittle (eds) 2007, 65-84

Zvelebil, M. \& Lukes, A. 2008. Inter-generational transmissions of culture and LBK origins: some indications from eastern-central Europe. In D. Bailey, A. Whittle and D. Hofmann (eds), Living Well Together? Settlement and Materiality in the Neolithic of South-east and Central Europe, 139-51. Oxford: Oxbow Books

\section{RÉSUMÉ}

Dates, nutrition et démembrement: témoignages du monument mégalithique de Coldrum, Kent, de Michael Wysocki, Seren Griffiths, Robert Hedges, Alex Bayliss, Tom Higham, Yolanda Fernandez-Jalvo et Alasdair Whittle

Nous présentons ici des données radiocarbone et d'isotopes stables et des analyses ostéologiques des restes d'un minimum de 17 individus déposés dans la partie ouest de la chambre funéraire de Coldrum, Kent. Coldrum fait partie du groupe de monuments néolithiques de Medway, des sites qui ont en commun des motifs architecturaux et n'ont pas de proche parallèle ailleurs en Grande-Bretagne. On a considéré que leur emplacement dans le Kent était important en matière d'origines de la culture et des pratiques matérielles néolithiques en Grande-Bretagne. L'analyse ostéologique a identifié le plus important assemblage d'ossements 
humains portant des traces de coupure répertorié jusqu'alors d'un monument funéraire du néolithique ancien dans le sud de la Grande-Bretagne, ces modifications avaient probablement été exécutées dans le cadre de pratiques funéraires néolithiques. L'ensemble des données d'isotopes stables montre des valeurs de $\delta^{15} \mathrm{~N}$ très enrichies dont les causes ne sont pas tout à fait claires, mais pourraient comprendre la consommation des ressources en poissons d'eau douce. Le modèle statistique bayesien des datations au radiocarbone disponibles démontre que Coldrum est un exemple ancien de monument funéraire néolithique en Grande-Bretagne, bien que ce monument n'ait peut-être pas fait partie des plus anciens vestiges néolithiques du Grand Estuaire de la Tamise. Ce site fut probablement utilisé pour la première fois après l'apparition initiale d'autres vestiges régionaux du néolithique ancien, y compris une sépulture à inhumation, de la céramique du néolithique ancien, une structure à poteaux et encoches caractéristique du néolithique ancien et l'extraction de silex néolithique dans les mines du Sussex. Coldrum est le seul site du groupe des monuments de Medway dont des échantillons ont été datés au carbone 14, et il est important à la fois pour les études régionales du néolithique et les narrations plus étendues des procédés, du temps et du tempo de la néolithisation de la Grande-Bretagne.

\section{ZUSSAMENFASSUNG}

Daten, Diät, Disartikulation: Neue Beobachtungen zum Megalithen von Coldrum, Kent, von Michael Wysocki, Seren Griffiths, Robert Hedges, Alex Bayliss, Tom Higham, Yolanda Fernandez-Jalvo und Alasdair Whittle

Dieser Beitrag präsentiert Daten aus Radiokarbon- und Isotopenuntersuchungen sowie osteologische Analysen von den Überresten von mindestens 17 Individuen, die im westlichen Teil der Grabkammer von Coldrum, Kent, deponiert worden waren. Coldrum ist eine Megalithanlage aus der neolithischen Medway Gruppe, einer Reihe von Monumenten mit gleichartigen architektonischen Merkmalen und ohne nennenswerte Parallelen im Rest Großbritanniens. Ihre Positionierung in Kent wurde als bedeutsam für die Ursprünge der neolithischen materiellen Kultur und Lebensweise in Großbritannien erachtet. Die osteologische Analyse erbrachte die umfangreichste Anzahl an menschlichen Knochen mit Schnittspuren, die je in einem südbritischen frühneolithischen Grabmonument beobachtet wurde; diese Eingriffe in den menschlichen Körper wurden vermutlich als Teil neolithischer Bestattungssitten vorgenommen. Die Datenserien zu stabilen Isotopen zeigen sehr hohe $\delta^{15} \mathrm{~N}$-Werte; die Gründe hierfür sind nicht völlig klar, doch könnten sie in der Konsumption von Ressourcen von Süßwasserfischen liegen. Bayes'sche statistische Berechnungen der vorhandenen Radiokarbondaten zeigen, dass Coldrum ein frühes Beispiel eines neolithischen Grabmonuments in Großbritannien ist, auch wenn das Grab vielleicht nicht zu den Belegen des ältesten Neolithikums im Themsemündungsgebiet gehört. Der Fundort wurde vermutlich zum ersten Mal nach dem ersten Auftauchen anderer frühneolithischer regionaler Erscheinungen genutzt, zu denen auch ein Körpergrab, frühneolithische Keramik, eine charakteristische frühneolithische Pfosten-und-Schlitz-Struktur und neolithischer Flintabbau in den Minen von Sussex gehören. Coldrum ist der einzige Ort innerhalb der Medway Gruppe, der Proben erbrachte, die C14 datiert werden konnten, weshalb er bedeutsam ist für sowohl regionale Untersuchungen zum Neolithikum als auch generelle Studien zum Vorgang, zeitlichen Ablauf und Tempo der Neolithisierung Großbritanniens.

\section{RESUMEN}

Dataciones, dieta y desmembramiento: evidencia del monumento megalítico de Coldrum, Kent, por Michael Wysocki, Seren Griffiths, Robert Hedges, Alex Bayliss, Tom Higham, Yolanda Fernandez-Jalvo y Alasdair Whittle

Se presentan las dataciones de radiocarbono, los datos de isótopos estables y los análisis osteológicos de los restos de un mínimo de 17 individuos depositados en la parte oeste de la cámara funeraria de Coldrum, Kent. Coldrum es uno de los monumentos megalíticos del conjunto de monumentos neolíticos de Medway - sitios que comparten motivos arquitectónicos y sin otros ejemplos similares en el resto de Gran Bretaña. Su situación en Kent se ha considerado especialmente relevante en relación con los orígenes de la cultura material y de las 
prácticas neolíticas en Gran Bretaña. El análisis osteológico identificó el mayor conjunto de restos humanos con marcas de corte procedente de un monumento funerario del Neolítico inicial en el sur de Gran Bretaña; estas modificaciones fueron probablemente llevadas a cabo como parte de las prácticas funerarias neolíticas. Los datos de los isótopos estables reflejan valores muy elevados de $\delta^{15} \mathrm{~N}$, cuyas causas no están muy claras, aunque podría deberse al consumo de peces de agua dulce. El modelo estadístico bayesiano de las dataciones de radiocarbono disponibles demuestra que Coldrum es un ejemplo muy temprano de un monumento funerario Neolítico en Gran Bretaña, aunque el monumento quizás no forme parte de las primeras evidencias neolíticas en el Gran Estuario del Támesis. Probablemente se inició el uso de este sitio tras la aparición de otras evidencias anteriores del Neolítico inicial, incluyendo una inhumación, cerámica del Neolítico antiguo, una estructura de postes característica del Neolítico inicial, y la extracción neolítica de sílex en las minas de Sussex. Coldrum es el único sitio del grupo de monumentos Medway que tiene muestras datadas por radiocarbono, y es importante tanto para los estudios regionales sobre Neolítico como para estudios más amplios de los procesos, duración y ritmo de la Neolitización en Gran Bretaña. 